\title{
Research
}

\section{Periodic Closures as Adaptive Coral Reef Management in the Indo- Pacific}

\author{
$\underline{\text { Josh Cinner }}{ }^{1}$, Michael J. Marnane ${ }^{2}, \underline{\text { Timothy R. McClanahan }}{ }^{2}$, and Glenn R. Almany ${ }^{1}$
}

\begin{abstract}
This study explores the social, economic, and ecological context within which communities in Papua New Guinea and Indonesia use adaptive coral reef management. We tested whether periodic closures had positive effects on reef resources, and found that both the biomass and the average size of fishes commonly caught in Indo-Pacific subsistence fisheries were greater inside areas subject to periodic closures compared to sites with year-round open access. Surprisingly, both long-lived and short-lived species benefited from periodic closures. Our study sites were remote communities that shared many socioeconomic characteristics; these may be crucial to the effectiveness of adaptive management of reef resources through periodic closures. Some of these factors include exclusive tenure over marine resources, a body of traditional ecological knowledge that allows for the rapid assessment of resource conditions, social customs that facilitate compliance with closures, relatively small human populations, negligible migration, and a relatively low dependence on fisheries. This dynamic adaptive management system, in which communities manage their resources among multiple social and ecological baselines, contrasts with western fisheries management practices, centered on maintaining exploited populations at stable levels in which net production is maximized.
\end{abstract}

Key Words: adaptive management; coral reefs; socioeconomic; periodic closures; traditional management; social-ecological systems

\section{INTRODUCTION}

Coral reefs are one of the most productive and biologically diverse environments on Earth (Paulay 1997, Reaka-Kudla 1997). Most reefs occur in developing nations in which they are often heavily relied upon as a source of food and, in many cases, economic development. Growing coastal populations and increased resource extraction rates have put coral reefs at a high risk of catastrophic biodiversity loss, which would likely have severe consequences for the productivity of these systems and the human populations that depend upon them (Wilkinson 2002, Hughes et al. 2003, Hooper et al. 2005). As a result, developing effective management strategies for coral reefs has become one of the foremost challenges confronting conservation scientists and managers.

One of the primary extractive activities on reefs is fishing. Two general categories of management strategies have been implemented or proposed for coral reef fisheries (Polunin and Roberts 1996). First, borrowing from conventional fisheries management common in developed nations, various combinations of gear restrictions, size limits, catch quotas, temporal restrictions during vulnerable life stages, e.g. spawning aggregations, and other methods of effort reduction, e.g., permitting, alternative income projects, etc., have been attempted or suggested as solutions. However, such complex measures are difficult to administer or enforce in developing nations and; therefore, they frequently prove to be of limited utility (Russ 2002). As an alternative, a second management strategy has been proposed by a number of scientists and conservation practitioners, establishing networks of fully protected marine reserves within which extractive activities are prohibited (Hall 1998, Fogarty 1999). Efforts to establish reserves in developing nations have faced a variety of problems. For example, closed areas often displace or marginalize subsistence fishers, resulting in increased conflict over marine resources (Christie 
2004). As a result, the use of fully closed reserves as fishery management in developing countries has, at present, achieved limited success (McClanahan 1999, Pollnac et al. 2001).

At first glance, conventional techniques and marine reserves appear to differ considerably in their approach to fisheries management, but both are based on a similar principle, i.e., harvesting "surplus" production (Guénette et al. 1998, Caddy 1999). Caddy (1999) has argued that surplus production theory arose in the 1930s and has formed the basis for the overriding concept in conventional management, maximum sustainable yield (MSY). Generally, regulations seek to control fishing effort or catch characteristics, e.g., fish size, such that population size/biomass is maintained at a predetermined level that produces the greatest surplus of harvestable biomass and; therefore, provides the greatest benefit to the fishery. Marine reserves function similarly, for they allow population size and biomass to increase to, and be maintained at, the natural carrying capacity of the reserve habitat (Guénette et al. 1998). Excess production from the reserve population, whether in the form of adult spillover or export of larvae, can theoretically be harvested by adjacent fisheries (Russ 2002). Although the goals are different, both management approaches assume, or seek to achieve, a stable population equilibrium, a concept that has created considerable discussion (Earn and Rohani 1999, Lloyd and May 1999).

One potential alternative is a dynamic cycle of prohibiting and allowing harvesting within prescribed areas. Such periodic closures of tropical marine resources are well documented in traditional societies (Johannes 1982, Hviding 1996, Ruttan 1998, Colding and Folke 2000, 2001, Aswani and Weiant 2004), but the ecological consequences of these practices on coral reef ecosystems are not well understood. As a result, periodic closures are rarely used in conventional coral reef management, and we know little about the ability of such techniques to manage reef fisheries, conserve reef resources, or protect biodiversity.

Our recent research has integrated social and biological sciences to explore resource use and customary management in Melanesia in the modern conservation context (Cinner et al. 2005ab, Cinner and McClanahan, in press). In this paper, we attempt to build upon these studies by presenting two case studies of the ecological and socioeconomic context in which traditional periodic closures operate: one from a village in the Madang Province of Papua New Guinea, and another from a village in North Sulawesi, Indonesia. Our goals were: (1) to examine whether and how periodic closures influence reef resources; (2) to examine how these systems may differ from conventional fisheries management and conservation models; and (3) to identify the social, economic, and cultural mechanisms that may influence the ability of communities to successfully manage their resources through periodic closures.

\section{BACKGROUND AND STUDY SITES}

\section{Cultural context of resource governance}

Some communities in the Indo-Pacific use customary marine tenure to prevent "outsiders" from exploiting resources (Malinowski 1922, 1935, Hviding 1983, Polunin 1984, Wright 1985, Carrier 1987, Hviding 1996, Mantjoro 1996, Ruttan 1998, Aswani 1999, Aswani 2002, Johannes 2002a). Additionally, some communities have certain practices, beliefs, and dietary restrictions that limit their own resource use. Together, these practices have been variously termed "traditional management," "taboos," "folk management," and "local management" (Dyer and McGoodwin 1994, Pollnac and Johnson 2005), and can take a variety of forms: banning a particular type of harvesting gear (Hviding 1996, Johannes 1981, 2002b), temporal or seasonal harvesting restrictions (Hviding 1996, Johannes 1978), gear-restricted areas that are occasionally harvested (Cinner et al. 2005a), and periodic closures (Hviding 1983, Polunin 1984, Wright 1985). A considerable amount of ethnographic work has focused on describing the historical and cultural mechanisms that have led to these practices. Our goal was to build on this previous work by exploring these issues using a different approach: synchronic socioeconomic and ecological research.

Due to the high cost of providing Self Contained Underwater Breathing Apparatus (SCUBA) support for ecological research in remote locations, we were restricted to $10 \mathrm{~d}$ of data collection at each of our two field sites. A key limitation of this timerestricted approach is that some important historical and cultural processes that may take ethnographers years to unravel, e.g., genealogies, could not be explored. We acknowledge that synchronic 
research does have limitations in this type of study, but hope that the insights gained by simultaneously investigating socioeconomic and ecological data outweigh the costs of our inability to incorporate the diachronic research typically used in sociocultural studies of traditional management.

\section{Kakarotan, Sangihe-Talaud Archipelago, North Sulawesi, Indonesia}

Kakarotan Island, in the northernmost reaches of the Sangihe-Talaud archipelago, is a small coral cay with a population of approximately 730 people in 144 households (Fig. 1). A system of periodic reef closures called mane'e is practiced; each year, one of nine reef areas is closed for a period, and then opened to harvest fish for a traditional ceremony. The mane' $e$ practice starts with a taboo on all fishing activities within one area (Fig. 1). The taboo generally lasts for six months, although this can vary with social and ecological concerns. Site selection and duration of the taboo are decided during a meeting of the community's traditional leaders. There appeared to be no systematic method for selecting which area would be closed, although the location of the closure was said to frequently switch between sites from year to year. In recent years, one the largest mane'e areas, $(\sim 50 \mathrm{ha})$ had been closed several times. The boundaries of this largest area ranged from the shoreline to the bottom of the reef slope. During the lowest tide of a specified month, the community collectively harvests the closed area to provide fish for a large feast.

The origin of this practice and the original purpose of the feast were unclear, and community leaders and elders cited tradition as the dominant factor (this is not uncommon, see Berkes et al. 2000, Pollnac and Johnson 2005). Observing the annual harvest and participating in the feast has recently become an attraction for Indonesians from the Sulawesi mainland, and attracting these tourists was cited as a secondary reason for the closure. Sanctions exist for violations of the taboo; a warning is given on the first offense and a fine on the second. Most mane'e areas are clearly visible from the community, and fishers tended to fish in groups of 10-20 canoes, thereby making it difficult for individuals to break community rules and increasing the chance of their detection and reporting. At the time of our study, the closure was not in effect and extractive activities were permitted in the mane'e area. Our research in Kakarotan occurred over $10 \mathrm{~d}$ in September 2002.

\section{Muluk Village, Karkar Island, Madang Province, Papua New Guinea (PNG)}

The Muluk community, on the eastern side of Karkar Island, consisted of approximately 330 people in 50 households (Fig. 1). Muluk claims exclusive-use rights over reefs along the entire coastline adjacent to their village and the neighboring village of Wadau. In Muluk, management consists of closing approximately 58 ha of reef adjacent to the village for 1-2 yr, whenever the village chiefs notice that the fish catch is declining. Chiefs cited their own fishing experience, their observations of low catches at landing sites by other fishers, and reports by fishers that fish were remaining "too far away" as ways that they "noticed" declining catches. The explicitly stated reason for periodic closures was that fish "would become easier to catch" after some period of closure, particularly while spearfishing. Resource users explained that when heavily fished, reef fishes altered their behavior such that they remained farther away from fishers, and were therefore more difficult to catch. By periodically closing the resource to extractive activities, it was thought that reef fishes would become more "tame," thereby allowing fishers to catch fish more effectively. The decision to close reefs is reached through a consensus between the three clan-chiefs. The reef closure in Muluk generally occurred 2-3 times within a 10-yr span. At the time of our study, the area had been closed for approximately 6 mo. Key informants were unclear as to when this periodic closure system began, but could confirm its presence for at least $60 \mathrm{yr}$. Our research in Muluk occurred over $10 \mathrm{~d}$ in December 2001.

\section{METHODS}

\section{Assessment of reef resources}

To test for effects of periodic closures on biological resources, we compared three randomly-selected sites within the managed area to three control sites outside the managed area at Kakarotan, and five managed sites and five control sites at Muluk. At both Kakarotan and Muluk, control sites were within $1.5 \mathrm{~km}$ of the managed area boundary. We used timed swims to estimate fish species richness, and we conducted line transects to obtain quantitative information on fish biomass, fish size, fish abundance, substratum composition, e.g., hard coral cover, etc., coral recruitment, abundance of 
Fig. 1. Map of study sites and periodic closures areas.

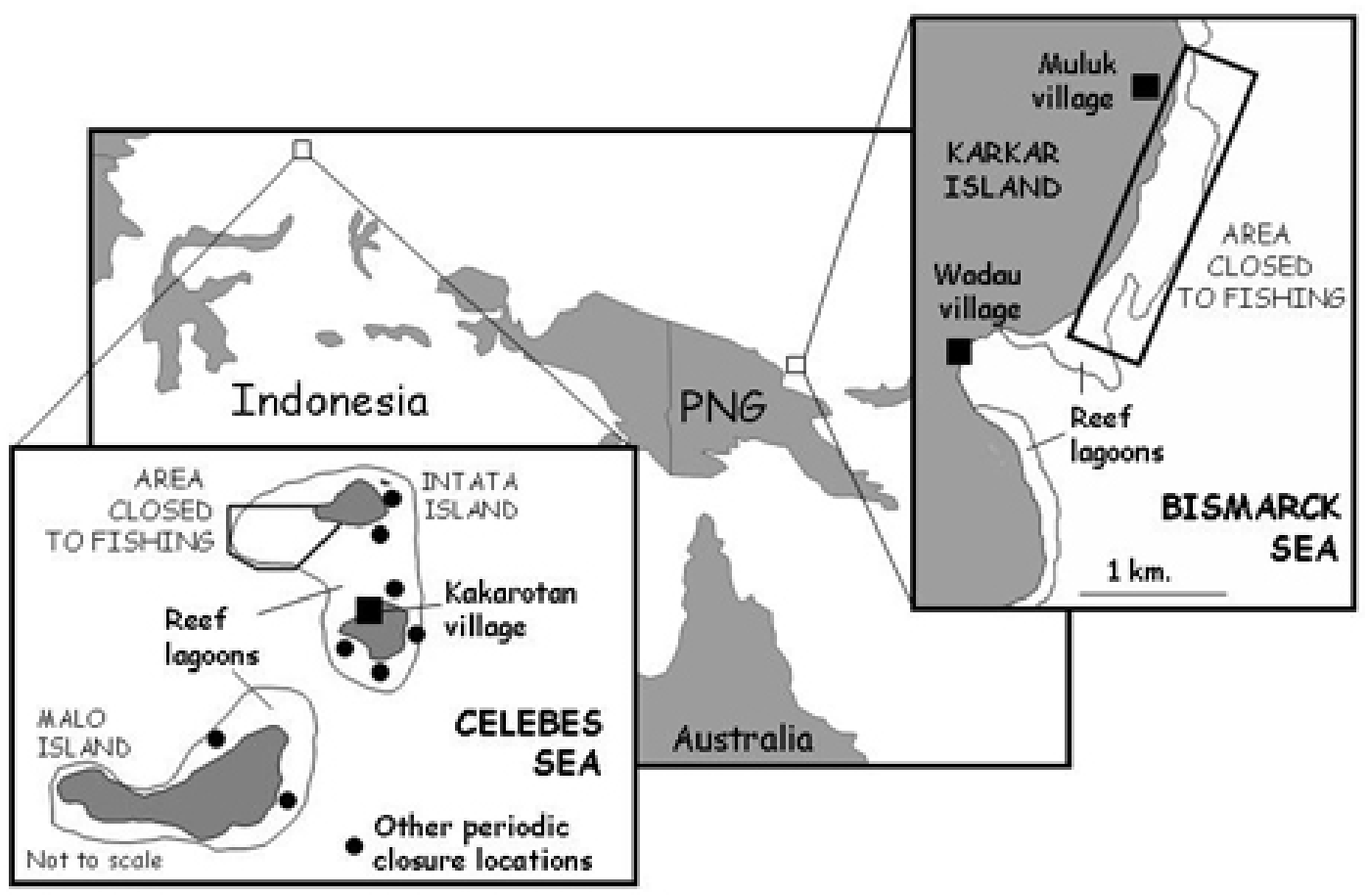

giant clams (Tridacna spp.), recent damage to coral from human activities, and the amount of discarded fishing gear. Giant clams were a focus of study because they are heavily exploited in this region, and a few species have been reduced to near extinction levels (Villanoy et al. 1988, Green and Craig 1999). Due to the limited time at each site, we were not able to study the seasonal patterns of fish or fish catch, but other more detailed studies have found that tropical benthic or reef fisheries exhibit low seasonality (McClanahan and Mangi 2000, PetSoede 2000).

To estimate total fish species richness, we randomly selected one starting point within the managed area and one starting point outside the managed area, and we recorded all noncryptic fish species encountered during a 1-hr swim on SCUBA. Cryptic fishes from four families, Apogonidae (cardinalfishes), Blenniidae (combtooth blennies), Gobiidae (gobies) and Tripterygiidae (threefin blennies) were excluded from our analyses. The path of the timed swim followed a haphazard, zigzag pattern on the reef to include all reef habitats from the shallow reef flat to the deeper reef base. Total survey area both within and outside the managed area was approximately 3.5 ha. We identified species based on descriptions and nomenclature of Allen and Swainston (1993), Randall et al. (1997), Myers (1999), and The International Center for Living Aquatic Resources 
Management: ICLARM Fishbase 2000 (Froese and Pauly 2000), and used the coral fish diversity index (CFDI) (Allen and Werner 2002) to quantify species richness.

At each of the six survey sites at Karkarotan and the 10 survey sites at Muluk, we recorded densities of all noncryptic species along three $50 \mathrm{~m}$ belt transects, placed haphazardly at two depths, i.e., 3 $\mathrm{m}$ and $7 \mathrm{~m}$. On each transect, we surveyed sedentary damselfish (Pomacentridae) within a $2 \mathrm{~m}$-wide belt, and the remaining families within a $5 \mathrm{~m}$-wide belt. We used discrete group sampling (DGS) to record fish abundance (Greene and Alevizon 1989); four passes were made over each transect, and during each pass we noted the abundance of fish from particular groups: Group 1: Pomacentridae, Group 2: Labridae (wrasse), Group 3: Acanthuridae (surgeonfishes), Scaridae (parrotfishes) and Siganidae (rabbitfishes), and Group 4: Balistidae (triggerfishes), Caesionidae (fusiliers), Chaetodontidae (butterflyfishes), Haemulidae (grunts), Lethrinidae (emperors), Lutjanidae (snapper), Nempteridae (threadfin breams), Pomacanthidae (angelfishes), and Serranidae (sea basses). We only recorded those fish that had a total length (TL) of $>3 \mathrm{~cm}$ to reduce the difficulties associated with sampling small juveniles, and the influence of sporadic recruitment episodes on abundance estimates. Surveys at $3 \mathrm{~m}$ depths were conducted while snorkeling, whereas surveys at $7 \mathrm{~m}$ were conducted using SCUBA. We used species-specific values from FishBase 2000 (Froese and Pauly 2000) to calculate mean trophic levels.

We examined the size structure of fish populations from the four groups along each $50 \mathrm{~m}$ transect during two passes along each transect. On the first pass, we recorded all fishes $\geq 10 \mathrm{~cm}$ total length (TL) within a $5 \mathrm{~m}$-wide belt. On the second pass, we recorded all fishes $\leq 10 \mathrm{~cm}$ TL within a $2 \mathrm{~m}$-wide belt. We identified and pooled all reef fishes and reefassociated fishes into family-level groupings, with relatively uncommon families grouped into a single "other" category. Each individual was assigned to one of five size categories: $3-5 \mathrm{~cm}, 5-10 \mathrm{~cm}, 10-20$ $\mathrm{cm}, 20-30 \mathrm{~cm}$, and $30-40 \mathrm{~cm}$. Size estimates of fish $>40 \mathrm{~cm}$ and fish of unusual shape, e.g., trumpetfish (Aulostomidae), were recorded to the nearest $1 \mathrm{~cm}$ to allow for more precise biomass conversions. For each family, we used representative length-weight conversions, obtained from FishBase 2000 (Froese and Pauly 2000) to convert size-frequency data into biomass data. For fish in the five size classes, we used the midpoint of the size class in biomass calculations. Whenever available, we used speciesspecific formulas to calculate biomass for fish $>40$ $\mathrm{cm}$ TL and fish of unusual shape.

We validated the accuracy and precision of underwater size estimates every 2-3 d by testing the ability of observers to correctly estimate the length of sections of PVC pipe. At each new site, 10 sections of numbered PVC pipe were placed underwater on a length of rope with attached weights. Observers estimated the length of each section and recorded its number from a distance of $5 \mathrm{~m}$, and we compared estimates to actual lengths. Estimates were generally within $10 \%$ of the actual lengths.

We estimated benthic cover composition at each site along 18 standard line-intercept transects (McClanahan and Shafir 1990), each of which had a length of $10 \mathrm{~m}$. We placed all transects parallel to the reef crest, with three transects laid flat along the reef two meters shoreward of the crest, three transects along the crest, and three transects on the reef slope at a depth of 2-3 m. A further nine transects, three at each depth, were surveyed on the reef slope at $6 \mathrm{~m}, 7 \mathrm{~m}$, and $8 \mathrm{~m}$. We recorded the type of benthic cover and linear distance occupied by each cover category along each transect. Benthic cover categories were as follows: hard coral, soft coral (alcyonaceans), sponges, sea grasses, gorgonians (gorgonaceans), zooanthids, anemones, ascidians, bryozoans, fleshy algae, turf algae, encrusting red algae, coralline algae, and sand. We identified hard corals, including the octocorals Heliopora, Millepora and Tubipora spp., to genus based on descriptions and the nomenclature of Veron (2000), and fleshy algae to species based on Allen and Steene (1994). To estimate coral diversity at each site, we used data on the cover of hard coral genera along line-intercept transects to calculate a Simpson's diversity index where diversity, $D$, is calculated as:

$D=1-\sum\left(n_{\mathrm{i}} / N_{t}\right)^{2}$

Where $\quad{ }^{n}$ is the cover of the individual genera and $N_{t}$ is the total coral cover (Magurran 2004).

We recorded the abundance of giant clams (Tridacna spp.) along four $1 \mathrm{~m} \times 100 \mathrm{~m}$ belt transects at each site, each laid flat along the reef, approximately $20 \mathrm{~m}$ shoreward of the reef crest. We used $0.0625 \mathrm{~m}^{2}$ quadrats to examine the density of 
coral recruits, defined as colonies between $0.5-5 \mathrm{~cm}$ in diameter, per unit area. To assess the effect of fishing activities on reefs, we recorded the presence of discarded fishing gear, including nets, fishing lines, and spears, along the same transects that were used for benthic cover and giant clam surveys. We also recorded recent coral damage, defined as pieces of coral broken off the main colony, but still alive, and recently upturned corals along these transects. There had been no recent storm activity in either of the study areas, so we assumed that coral damage was due to human activities. We noted corals damaged by fishes, e.g., humphead parrotfish (Bolbometapon muricatum), and excluded them from analyses.

To aid in comparisons with other studies, we converted ecological data into standard units such as ha or $\mathrm{m}^{2}$. Measures of variability were based on these converted units and not on the original units of measure. We used MANOVA to compare managed areas and control areas. When variables did not meet the assumptions of normality, we used a nonparametric Mann Whitney U-test (Siegel and Castellan 1988).

\section{Assessment of catch composition}

To determine the types of fishes targeted by fishermen and the types of gear used for their collection, we examined catch composition at Kakarotan over $10 \mathrm{~d}$. We observed a total of 1405 reef-associated fishes and used a digital camera (Sony DSC P-1, 3.3 megapixel) to record catch composition for use in species determination (Cinner and McClanahan, in press). We were unable to collect similar data at Muluk, because fishers were targeting a seasonal abundance of non reefassociated fishes (flyingfishes [Exocoetidae]) during our observation period and, thus, harvesting from the reef was minimal. Fishers suggested that fishing activities would regain focus on reef fishes once the abundance of flying fish had declined.

\section{Assessment of socioeconomic factors}

We used a combination of household surveys, key informant interviews, oral histories, and participant observation in resource use activities to gather information on fishing pressure, occupational diversity, immigration, governance of coastal resources, and awareness of and compliance with closures. We used the methods described by Henry (1990) to systematically sample 59 of the 144 households in Kakarotan, and we opportunistically sampled 41 of the 50 households in Muluk.

Questions in household surveys were directed toward the head of the household, i.e., male, female, or both depending on who was present at the time of the interview. We determined participation in fishing, agriculture, and other occupations by asking respondents to rank the occupations of their household from most to least important (Pollnac and Crawford 2000). We estimated fishing pressure by asking respondents how many days per week, on average, did each member of the household engage in specific fishing activities. We attempted to account for potential variation in seasonality of resource use activities by asking respondents about their activities in both the high and low fishing seasons, asking key informants about the average duration of the each season and averaging the total number of days for both seasons based on season length. We extrapolated these data to estimate the total fishing pressure on reef resources for each community. We used a finite population correction factor, which adjusts for error based on the proportion of the community surveyed (Scheaffer et al. 1996), to calculate errors for quantitative socioeconomic variables.

Depending upon the needs of a study, migration status can be defined in a variety of ways, including whether a person was born in another village or province, or belonged to a different language group, etc. Since use rights to marine resources in Papua New Guinea are often primarily delineated at the village level, we defined immigrants as individuals born in other villages.

We assessed awareness of closures by asking the fishers in our sample if there were places in which people were not supposed to fish. Fishers were asked to provide descriptive details of any places they mentioned. For the purposes of this question, we considered respondents fishers if they ranked fishing among their household's four most important occupations or livelihood strategies. To assess compliance with closures, we then asked fishers if people still fished in the closure area. We grouped their response to the compliance question into four ordinal categories: (1) nobody fishes there, (2) a few people fish there, (3) many people fish there, and (4) almost everybody fishes there. 
We used participant observations, oral histories, and five key informant interviews at each site, including fishers, traditional leaders, and elected officials to verify the accuracy of household survey responses and to gain a better understanding of the context of coastal resource use and management. We selected key informants using nonprobability sampling techniques, including convenience sampling, e.g., a respondent was approached when observed returning from fishing, or snowball sampling, i.e., community members suggest appropriate respondents. Resource user key informants were individually interviewed, although community leaders and elders were usually interviewed in the presence of others. Oral histories and key informant interviews consisted of open-ended questions used to probe respondents about specific fishing practices, why and how the closures were implemented, and the origin of the closure practice.

\section{Size of fishing grounds}

We calculated the areas of shallow-water fishing grounds, i.e. reef, sand, and seagrass, in Muluk by digitally tracing the edges of the reef, corresponding approximately to the $10 \mathrm{~m}$ depth contour, on a 1:100,000 aerial photograph, and calculating the area with the UTHSCSA Image Tool 2.0 (University of Texas Health and Science Center, San Antonio, USA). For Kakarotan, we estimated the area of the fishing grounds using a nautical chart, because we were unable to obtain aerial photographs or satellite images.

\section{RESULTS}

\section{Reef resources}

At both Muluk and Kakarotan, the biomass and the average lengths of targeted fishes were greater inside the managed area compared to control sites (Table 1). At Muluk, both fish biomass and average size were $25 \%$ greater, and families with greater biomass included Lutjanidae (snappers), Lethrinidae (emperors), Acanthuridae (surgeonfishes), Serranidae (sea basses) and Siganidae (rabbitfishes) (Table 2). At Kakarotan, fish biomass was $37 \%$ greater, average size was $17 \%$ greater, and families with greater biomass included Scaridae (parrotfishes), Pomacanthidae (damselfishes), Serranidae, Haemulidae (sweetlips), Nemipteridae (threadfin breams) and
Balistidae (triggerfishes) (Table 3). Families responding positively to closures have a range of life histories and included a substantial number of relatively long-lived species with low population doubling times (Tables 2 and 3, Appendices 1 and 2).

The mean trophic level of fish communities was greater inside the managed area at Muluk relative to control sites, but did not differ at Kakarotan (Table 1). At Muluk, the abundance of giant clams was significantly greater within the managed area, whereas coral recruitment and the amount of recent damage to corals were both lower within the managed area. No significant differences in any other ecological variables were detected between managed and control sites at either Muluk or Kakarotan (Table 1).

\section{Catch composition}

Spear guns, nets, and lines caught $84 \%, 14 \%$, and $2 \%$, respectively, of the 1405 fish captured by fishers at Kakarotan during our survey period. Although 28 fish families were represented in the catch, two families dominated, i.e., Acanthuridae, $50 \%$ of the catch, and Scaridae, $31 \%$ of the catch. Balistidae and Serranidae accounted for $3.4 \%$ and $2 \%$ of the catch, respectively (Table 4).

\section{Socioeconomic factors}

Livelihood strategies at both Kakarotan and Muluk were similar (Fig. 2). In both communities, households engaged in a range of livelihood activities. Kakarotan averaged $3.9 \quad(3.7,4.1)$ occupations per household (mean $\pm 95 \% \mathrm{CI}$ ), and Muluk averaged 3.3 (3.2, 3.4). Over $85 \%$ of households in both communities engaged in some fishing activity, but few households ranked fishing as their primary livelihood strategy. Agriculture was the primary occupation for most households in both communities, and in Kakarotan, over $80 \%$ of the households engaged in informal economic activities, such as weaving mats or owning a small shop.

Immigration to both communities was low: $7.5 \%$ of the respondents had immigrated to Muluk and 2.1\% had immigrated to Kakarotan. Community participation and interaction was high: $96 \%$ of the Kakarotan households and $62 \%$ of the Muluk households were involved in some type of 
Table 1. Comparison of ecological variables inside and outside periodic closure areas.

\begin{tabular}{|c|c|c|c|c|c|c|c|c|c|c|c|c|}
\hline & \multicolumn{6}{|c|}{ Muluk } & \multicolumn{6}{|c|}{ Kakarotan } \\
\hline & Inside & SE & Outside & SE & $F$ & $P$ & Inside & SE & Outside & SE & $F$ & $P$ \\
\hline $\begin{array}{l}\text { Target fish spp. } \\
\text { average size (cm } \\
\text { total length) }\end{array}$ & 11.1 & 0.2 & 8.9 & 0.3 & 28.8 & 0.001 & 10.3 & 0.3 & 8.9 & 0.2 & 13.8 & 0.02 \\
\hline $\begin{array}{l}\text { Average fish trophic } \\
\text { level (by weight) }\end{array}$ & 2.7 & 0 & 2.5 & 0 & 3.3 & 0.001 & 2.4 & 0 & 2.3 & 0.1 & 4.2 & NS \\
\hline $\begin{array}{l}\text { Coral recruits } \\
\left(\text { density per } \mathbf{m}^{2}\right)\end{array}$ & 4.7 & 0.4 & 7.6 & 0.7 & 12.7 & 0.007 & 1.1 & 0.4 & 0.4 & 0.1 & 2.6 & NS \\
\hline $\begin{array}{l}\text { Target fish spp. } \\
\text { biomass (kg/ha) }\end{array}$ & 377.6 & 12.2 & 301.1 & 28.4 & 6.1 & 0.038 & 139.1 & 4.6 & 101.3 & 10.4 & 11.1 & 0.03 \\
\hline $\begin{array}{l}\text { Discarded fishing } \\
\text { gears (density/ha) }\end{array}$ & 11.1 & 11.1 & 44.4 & 11.1 & 4.5 & 0.07 & 2.9 & 2.9 & 79.8 & 43.7 & & $<0.05^{\mathrm{U}}$ \\
\hline $\begin{array}{l}\text { Giant clams } \\
\text { (density/ha) }\end{array}$ & 410 & 288 & 0 & 0 & & $0.01^{\mathrm{U}}$ & 316.7 & 120.2 & 450 & 104.1 & 0.7 & NS \\
\hline $\begin{array}{l}\text { Recently damaged } \\
\text { coral }(\% \text { of live coral } \\
\left.\text { cover } \times 10^{-3}\right)\end{array}$ & 0 & 0 & 1.1 & 0.2 & & $0.01^{\mathrm{U}}$ & 8.6 & 6.1 & 0 & 0 & & $\mathrm{NS}^{\mathrm{U}}$ \\
\hline $\begin{array}{l}\text { Dominant coral } \\
\text { genera }\end{array}$ & Acropora & & Porites & & & NA & Porites & & Porites & & & NA \\
\hline $\begin{array}{l}\text { Dominant coral } \\
\text { genera ( } \% \text { of total } \\
\text { hard coral cover) }\end{array}$ & 29.6 & 2 & 31.4 & 4.5 & & NA & 53.6 & 4.3 & 44.4 & 14.6 & & NA \\
\hline $\begin{array}{l}\text { Maximum \# of coral } \\
\text { genera }\end{array}$ & 47 & & 51 & & & NA & 37 & & 35 & & & NA \\
\hline $\begin{array}{l}\text { Target fish } \\
\text { abundance (density/ } \\
\text { ha) }\end{array}$ & 3065.3 & 507.4 & 3004 & 395.4 & 0.1 & NS & 1971.1 & 112.8 & 2026.7 & 358.2 & 0.1 & NS \\
\hline
\end{tabular}




\begin{tabular}{lcccccccccccc}
\hline $\begin{array}{l}\text { Fish species richness } \\
\text { per site (CFDI) }\end{array}$ & 79.4 & 8 & 82.2 & 6.5 & 0.1 & NS & 82.3 & 3.78 & 87.3 & 5.2 & 0.6 & NS \\
Hard coral \% cover & 35.3 & 4.2 & 40.8 & 4.5 & 0.8 & NS & 5.2 & 0.3 & 4 & 2.1 & 0.1 & NS \\
Coral diversity (D) & 0.8 & 0 & 0.8 & 0 & 0.9 & NS & 0.6 & 0.1 & 0.7 & 0.1 & 0.5 & NS
\end{tabular}

community group, and $69 \%$ and $83 \%$ of households, respectively, were involved in community decision making.

Spear guns and line fishing comprised the majority of the fishing activity in both communities (Fig. 3). There was approximately four times more gross fishing effort in Kakarotan (827 \pm 197 fishing trips/ wk) as in Muluk (198 \pm 24 fishing trips/wk). This difference was largely due to the higher population of Kakarotan, but there was also slightly higher fishing effort per household in Kakarotan (5.4 \pm 1.3 fishing trips per household/wk) compared to Muluk $(4.0 \pm 0.5)$. Kakarotan had access to 265 ha of fishing ground compared to 92 ha at Muluk. Therefore, fishing pressure relative to fishing ground area was relatively low in both communities with 3.1 trips/ ha/wk in Karkarotan and 2.1 trips/ha/wk in Muluk.

Key informants in both communities noted that customary marine tenure institutions provided village leaders with the legal or de facto authority to prohibit outsiders from extracting resources from fishing grounds surrounding the villages and to prohibit everybody from extractive activities within periodic closure areas. Village leaders had the authority and autonomy to develop and adapt rules to change the location and duration of the closure to reflect ecological or social conditions. In considering where, when, and how long to implement periodic closures, decision makers appeared to use their understanding of socialecological systems to interpret threshold levels of social and ecological indicators, commonly referred to as traditional ecological knowledge. For example, in Muluk, decision makers identified the key indicator as the distance a fisher could approach a targeted fish before the fish fled. When village chiefs perceived that this distance was large, i.e., fish did not allow a close approach, they placed a taboo on the reef for an undetermined period. When they perceived that this distance was acceptably small and fish were easier to catch, the taboo was lifted. In Kakarotan, more rigid social factors influenced where and when a taboo was placed. The occurrence of an annual feast largely determined the amount of time an area was closed, and other social factors such as whether government officials were expected to attend the feast, influenced which area was selected for closure. However, environmental conditions also influenced Kakarotan's taboo, as the traditional leader kept the area closed for an entire yr during 1998-1999, coinciding with a severe El Niño bleaching event.

Initiation ceremonies and village feasts help to remind people of the rules and embed the closures within the culture. For example, in Muluk, individuals were required to undergo an initiation ceremony before participating in the flying fish fishery. During the initiation ceremony, which we witnessed, elders recited the rules and discussed appropriate fisher behavior. In Kakarotan, the closure area was harvested to provide fish for an annual feast, which was said to be an important cultural event garnering extensive community participation. Consequently, awareness of reef closures in both communities was high; approximately $98 \%$ of fishers in Kakarotan and $79 \%$ of fishers in Muluk reported awareness of traditional spatial restrictions in their fishing activities. Reported and observed compliance with reef closures was reasonably high, particularly considering there were no active enforcement patrols. Almost $91 \%$ of Kakarotan fishers reported that few or no people violated closure rules. Reported compliance at Muluk was lower, with 52\% of fishers reporting that few or no people violated closure rules. However, the lower incidence of discarded fishing gears inside managed areas at both Kakarotan and Muluk suggests that closures did reduce fishing effort (Table 1). 
Table 2. Muluk: Results of the one-way ANOVAs for comparisons of biomass, inside vs. outside closures, and a summary of life histories and resilience to overfishing. Adapted from Froese and Pauly (1995) for families commonly caught in subsistence Indo-Pacific fisheries.

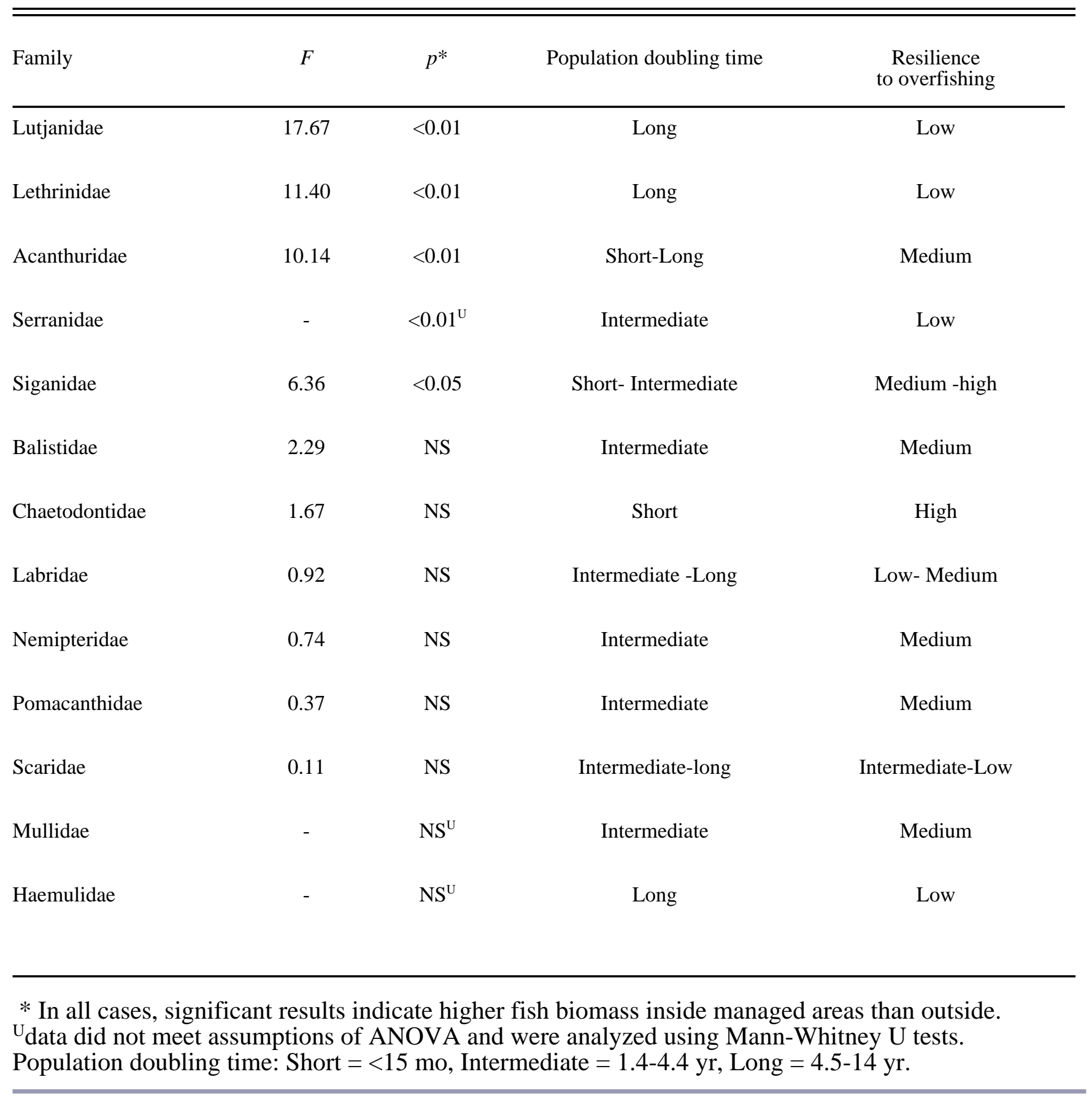


Table 3. Kakarotan: Results of the one-way ANOVAs for comparisons of biomass, inside vs. outside closures, life histories, and a summary of life histories and resilience to overfishing. Adapted from Froese and Pauly (1995) for families commonly caught in subsistence Indo-Pacific fisheries.

\begin{tabular}{|c|c|c|c|c|}
\hline Family & $F$ & $p^{*}$ & Population doubling time & $\begin{array}{l}\text { Resilience } \\
\text { to overfishing }\end{array}$ \\
\hline Scaridae & 46.49 & $<0.01$ & Short-long & Low-high \\
\hline Pomacanthidae & 9.28 & $<0.05$ & Short-Intermediate & Medium-High \\
\hline Serranidae & - & $<0.05^{\mathrm{U}}$ & Intermediate-Long & Low-Medium \\
\hline Haemulidae & - & $<0.05^{\mathrm{U}}$ & Long & Low \\
\hline Nemipteridae & - & $<0.05^{\mathrm{U}}$ & Short-Intermediate & Medium-High \\
\hline Balistidae & - & $<0.05^{\mathrm{U}}$ & Intermediate & Medium \\
\hline Lutjanidae & 1.31 & NS & Intermediate & Medium \\
\hline Lethrinidae & - & $\mathrm{NS}^{\mathrm{U}}$ & Long & Low \\
\hline Acanthuridae & 1.59 & NS & Short-Long & Low-High \\
\hline Siganidae & 1.00 & NS & Short & High \\
\hline Chaetodontidae & 2.13 & NS & Short-Intermediate & Medium-High \\
\hline Labridae & 6.69 & NS & Intermediate-Long & Low-Medium \\
\hline Mullidae & 2.09 & NS & Intermediate & Intermediate \\
\hline
\end{tabular}

* In all cases, significant results indicate higher fish biomass inside managed areas than outside. Udata did not meet assumptions of ANOVA and were analyzed using Mann-Whitney U tests. Population doubling time: Shor $<15 \mathrm{mo}$, Intermediate $=1.4-4.4 \mathrm{yr}$, Long $=4.5-14 . \mathrm{yr}$ 
Table 4. Fish families caught in Kakarotan fishing activities.

\begin{tabular}{|c|c|c|c|c|}
\hline Family & All gear & Speargun & Net & Line \\
\hline Acanthuridae & 50.4 & 48.6 & 65.8 & 15.4 \\
\hline Balistidae & 3.3 & 3.6 & 1.0 & 7.7 \\
\hline Belonidae & 0.1 & 0 & 0 & 3.8 \\
\hline Bothidae & 0.1 & 0.1 & 0 & 0 \\
\hline Carangidae & 0.4 & 0.2 & 0 & 11.5 \\
\hline Chaetodontidae & 0.4 & 0.3 & 1.0 & 0 \\
\hline Diodontidae & 0.3 & 0.3 & 0 & 0 \\
\hline Fistulariidae & 0.1 & 0.1 & 0 & 0 \\
\hline Hemulidae & 0.1 & 0.1 & 0 & 0 \\
\hline Holocentridae & 1.9 & 2.1 & 0 & 3.8 \\
\hline Kyphosidae & 0.9 & 1.0 & 0.5 & 0 \\
\hline Labridae & 2.2 & 2.2 & 2.0 & 3.8 \\
\hline Lethrinidae & 2.1 & 2.4 & 0.5 & 0 \\
\hline Lutjanidae & 1.0 & 1.1 & 0 & 3.8 \\
\hline Monocanthidae & 0.3 & 0.3 & 0 & 0 \\
\hline Mullidae & 0.2 & 0.1 & 0 & 7.7 \\
\hline Nemipteridae & 0.6 & 0.6 & 0 & 7.7 \\
\hline Ostraciidae & 0.2 & 0.1 & 1.0 & 0 \\
\hline Pempheridae & 0.1 & 0.1 & 0 & 0 \\
\hline
\end{tabular}




\begin{tabular}{|c|c|c|c|c|}
\hline Pomacentridae & 0.4 & 0.2 & 1.5 & 0 \\
\hline Priacanthidae & 0.1 & 0.1 & 0 & 0 \\
\hline Scaridae & 31.4 & 33.0 & 26.1 & 0 \\
\hline Scombridae & 0.2 & 0 & 0 & 11.5 \\
\hline Serranidae & 2.0 & 1.9 & 0 & 23.1 \\
\hline Siganidae & 0.5 & 0.5 & 0.5 & 0 \\
\hline Zanclidae & 1.0 & 1.2 & 0 & 0 \\
\hline$N$ & 1405 & 1180 & 199 & 26 \\
\hline
\end{tabular}

\section{DISCUSSION}

At both Muluk, Papua New Guinea, and Kakarotan, Indonesia, we found that the biomass and the average size of fishes commonly caught in IndoPacific subsistence fisheries were greater inside areas subject to periodic closures compared to sites with year-round open access. Surprisingly, both long and short-lived species benefited from periodic closures. Our study sites were remote communities that shared many socioeconomic characteristics; these may be crucial to the effectiveness of adaptive management of reef resources through periodic closures. Some of these factors include exclusive tenure over marine resources, a body of traditional ecological knowledge that allows for the rapid assessment of reef resources, social customs to bolster compliance with closures, a relatively low human population size, negligible migration, and a relatively low dependence on fisheries. This dynamic adaptive management system contrasts strongly with western fisheries management practices, centered on maintaining exploited populations at stable and high surplus production levels.

\section{Effects of periodic closures on reef resources}

This study suggests that periodic closures can have significant positive benefits for coral reef fisheries. In both Indonesia and Papua New Guinea, we found that fish biomass and average fish size were greater inside the managed areas relative to the openlyfished control sites. We did not detect any differences in abundance between managed and control sites. However, fish density was extremely variable among sites, a trend reported in a number of other studies (Russ and Alcala 1998a, Dulvy et al. 2004). Such variability in abundance among sites could make detecting any differences in abundance between managed and control sites difficult. Studies of closed areas on coral reefs that have been opened to fishing show that fish biomass can be depleted rapidly, often within a few months (Russ and Alcala 1998b, McClanahan and Mangi 2000). In contrast, recovery to pre-exploitation levels can take years to decades (McClanahan 2000, Russ and Alcala 2004, McClanahan and Graham 2005), especially for species possessing life history characteristics that make them especially susceptible to fishing, including long-lived and slow-growing species with slow population growth rates. As a result, we predicted that periodic closures would most benefit species resilient to exploitation, i.e., short-lived and fast-growing species with fast population growth rates. Contrary to our expectations, we found that 
Fig. 2. Distribution of occupations in Muluk and Kakarotan, highlighting the proportion engaged as a primary occupation.

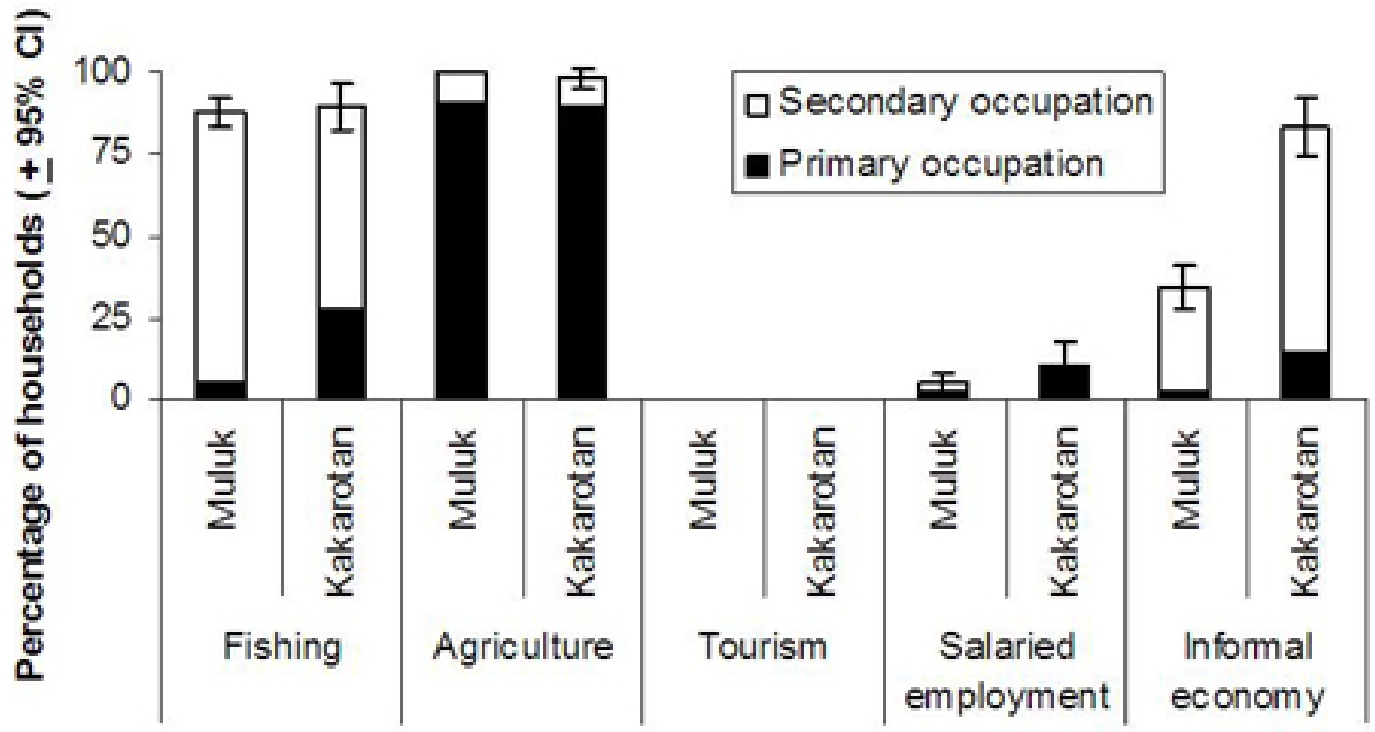

both biomass and average size was greater inside managed areas for several families characterized by high longevity, low natural mortality, and low somatic and population growth.

Although this result demonstrates that the effects of periodic closures were long lasting, it does not explain why such species would benefit from this type of management. One likely explanation is that periodic closures reduce overall fishing pressure inside managed areas, and as a result, long-lived, slow-growing species suffer lower mortality and; therefore, persist longer inside managed areas relative to openly fished sites. The critical assumption here is that fishing pressure inside a managed area opened to fishing is similar to that in areas that are always open to fishing. Our observations of fishing activities at Kakarotan support this assumption, although more intensive research on foraging practices would be required to determine the spatial distribution of fishing effort (Aswani 1998). Consistent with this hypothesis, in Kakarotan, species of Scaridae were heavily exploited; they ranked second in importance and included more than $30 \%$ of the catch we observed, but they had significantly greater biomass inside the 
Fig. 3. Fishing trips/wk by gear type for Muluk and Kakarotan.

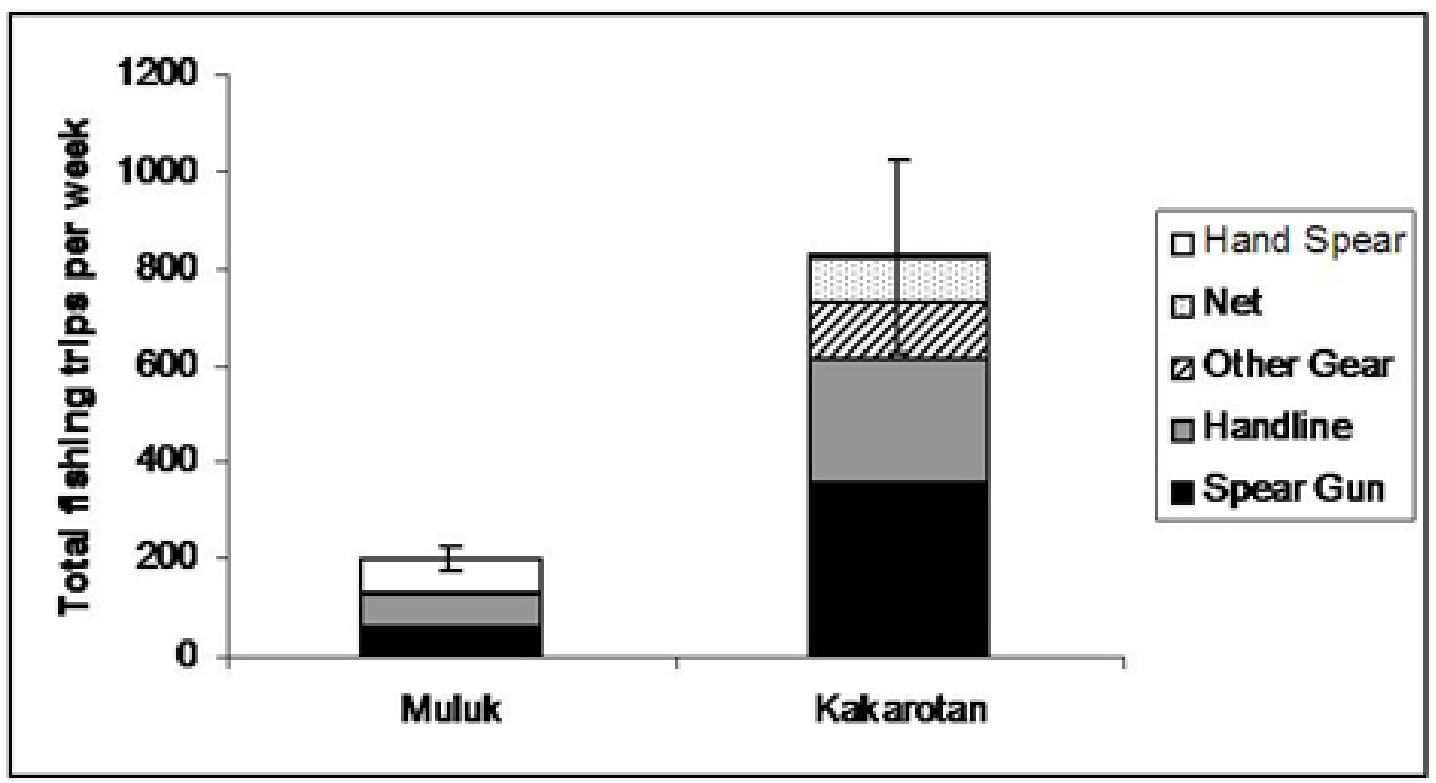

managed area. Although our sampling was inadequate to characterize the annual fish catch, our results of the families that are exploited with the gears used in Kakarotan are consistent with other studies examining gear selectivity (Pet-Soede 2000, McClanahan and Mangi 2004, Cinner and McClanahan, in press). Furthermore, the higher abundance of discarded fishing gear in fully fished areas at both locations suggests lower fishing pressure inside managed areas. In situations in which fishing pressure within a previously closed area is as great or greater than it is in fully opened fished areas, periodic closures would not likely benefit fisheries (Russ and Alcala 2003). Alternatively, long-lived, slow-growing species may only be targeted in fully opened sites, yet avoided in managed areas. However, our qualitative observations of fish catches in Kakarotan do not support this suggestion. Additionally, although long-lived species made up only a minor portion of the catches in Kakarotan, suggesting they are not heavily targeted, this cannot explain why biomass of these families was greater inside the managed area. Therefore, we suggest that the positive effects of periodic closures were likely caused by an overall reduction in fishing pressure inside the managed area.

In addition to fish biomass and average fish size, periodic closures had a relatively minor effect on 
other ecological variables. At Muluk, average trophic level of fishes, human-induced coral damage, and abundance of giant clams were greater within the managed area, although the density of coral recruits was greater in fully open control sites. At Kakarotan, there was no difference between managed and control sites. The absence of a strong effect on other key ecological variables such as species richness, is not surprising given the relatively low levels of exploitation, relative to other parts of Southeast Asia, at Muluk and Kakarotan, and small differences between managed and unmanaged sites.

\section{Comparisons with conventional fisheries management strategies}

The adaptive management practices we present in this paper are based on a different conceptual framework than conventional sustainable yield and full closed area models. Here, we develop a conceptual model to highlight some of the ways that these systems differ. Conventional fisheries management techniques, whether they rely on methods of fishing effort reduction or the full closure of defined areas such as marine reserves, manage resources to maintain relatively stable population sizes of harvested organisms and extract surplus production (Fig. 4a,b). In contrast, periodic closures seek to build a surplus of natural resources that can then be harvested. The adaptive cases we studied at Muluk and Kakarotan managed resources between two dynamic baselines or thresholds: a low baseline that signals community leaders to place a taboo ceasing resource extraction and a high baseline that signals community leaders to lift the taboo and resume extraction (Fig. 4c).

Whereas yield-based fisheries and marine reserve theories attempt to consistently maximize economic and ecosystem benefits, periodic closures aim to meet the cyclical needs of coastal communities. Any conservation effects are potentially only byproducts of other activities, in this case, community needs, a term referred to as epiphenomenal conservation (see Ruttan and Borgerhoff Mulder 1999). This cyclical system of prohibiting resource use then receiving direct benefits from the closure can lead to very different expectations between communities and conservationists on the purpose and duration of reef closures. Foale and Manele (2004) note that the customary model is akin to saving money then spending it all, and the western model is akin to keeping money in the bank and living off of the interest. Highlighting these differences is important because the practices, expectations, and enabling mechanisms associated with these periodic closures contrast strongly with those associated with western conservation and management.

\section{Socioeconomic factors associated with periodic closures}

Socioeconomic factors, or their lack of consideration in resource management planning, can cause marine conservation efforts to fail (Christie et al. 2003). This is because social, economic, and cultural factors influence whether individuals and communities create incentives to overexploit common-property resources or, alternatively, cooperate to successfully manage them (Ostrom 1990, Pretty 2003). Recent literature has highlighted the importance of social dimensions such as social capital, knowledge, and flexibility in adaptive management of social-ecological systems (Olsson et al. 2004, Folke et al. 2005). Here we build upon this framework by speculating on how these and other mechanisms may enable these communities to make use of periodic closures. These factors may be best explored in our study by breaking down the adaptive management cycle into four phases, i.e., placing the taboo, observing the taboo, lifting the taboo/harvesting resources within managed areas, and evaluating the condition of the resource, then investigating the social, economic, and cultural factors that may influence each phase (Fig. 5).

The first component, placement of the taboo, may have been facilitated by flexibility in the resource governance structure (Gunderson 1999, Dietz et al. 2003, Folke et al. 2005), the small human population size, and a moderate to low dependence on the resource. Highly decentralized customary marine tenure regimes nested within national or provincial authorities provided community leaders with the authority to develop and implement locally appropriate rules and sanctions virtually at will and with minimal bureaucracy (Hviding 1998). The relatively low dependence on fisheries and high degree of occupational multiplicity allows community members to switch to other occupations when restrictions are in place. This diversity of livelihood options minimizes economic displacement from the closures and allows the communities the 
Fig. 4. Comparison of models (a) sustainable fisheries management, (b) closed areas, and (c) adaptive management using periodic closures.

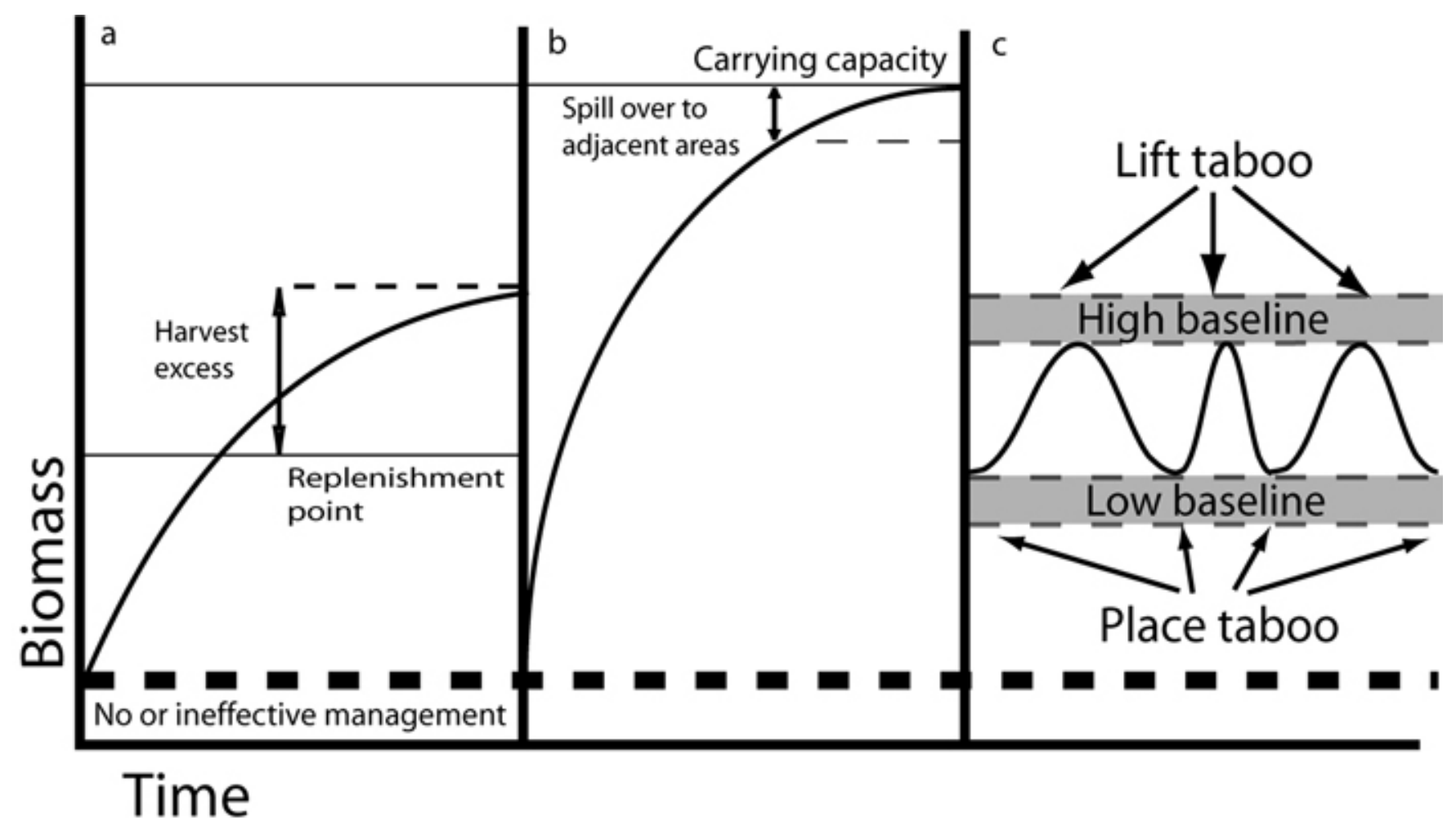

added livelihood security of replenishing natural resources within closures. In communities in which dependence on marine resources is higher and there are fewer available livelihood options, periodic or permanent closures, covering large proportions of fishing areas, may create significant economic displacement and disadvantages and may; therefore, be met with resistance.

The second component, compliance with the taboo, was likely facilitated by several socioeconomic factors. These include the exclusion of outsiders and high social capital, as indicated by low migration (Curran and Agardy 2002), and a high degree of group interaction (Ostrom 1990), including membership in community groups, social mechanisms that embed the closures in the culture, appropriate and graduated sanctions, and the ease of monitoring the closures. Flexibility in governance is coupled with the legitimate, or $d e$ facto, ability to exclude outsiders from accessing marine resources, which can be an important factor in the governance of common resources (Dietz et al. 2003). The communities we studied are relatively small, so the transaction costs of cooperation and collective action such as developing, monitoring, and enforcing rules, are relatively low (Ostrom 1990, Anderies et al. 2004). Low migration into these communities, a single religious institution in each community, and high incidences of daily interaction and cooperation provided culturally and religiously homogenous populations with high social capital, as measured by social bonds and norms (Scheffer et al. 2002, Pretty 2003), and shared world views (Berkes et al. 2000).

The low migration in these communities is not necessarily common in coastal communities in the region (Cinner 2005, Kramer et al. 2002, Koczberski and Curry 2004), and may have important implications for the integrity of their respective resource governance institutions. Both 
Fig. 5. Conceptual model of adaptive management phases. Each phase, i.e., placing, observing, and lifting the taboo, and evaluating the social-ecological system is facilitated by specific social, economic, and cultural factors.

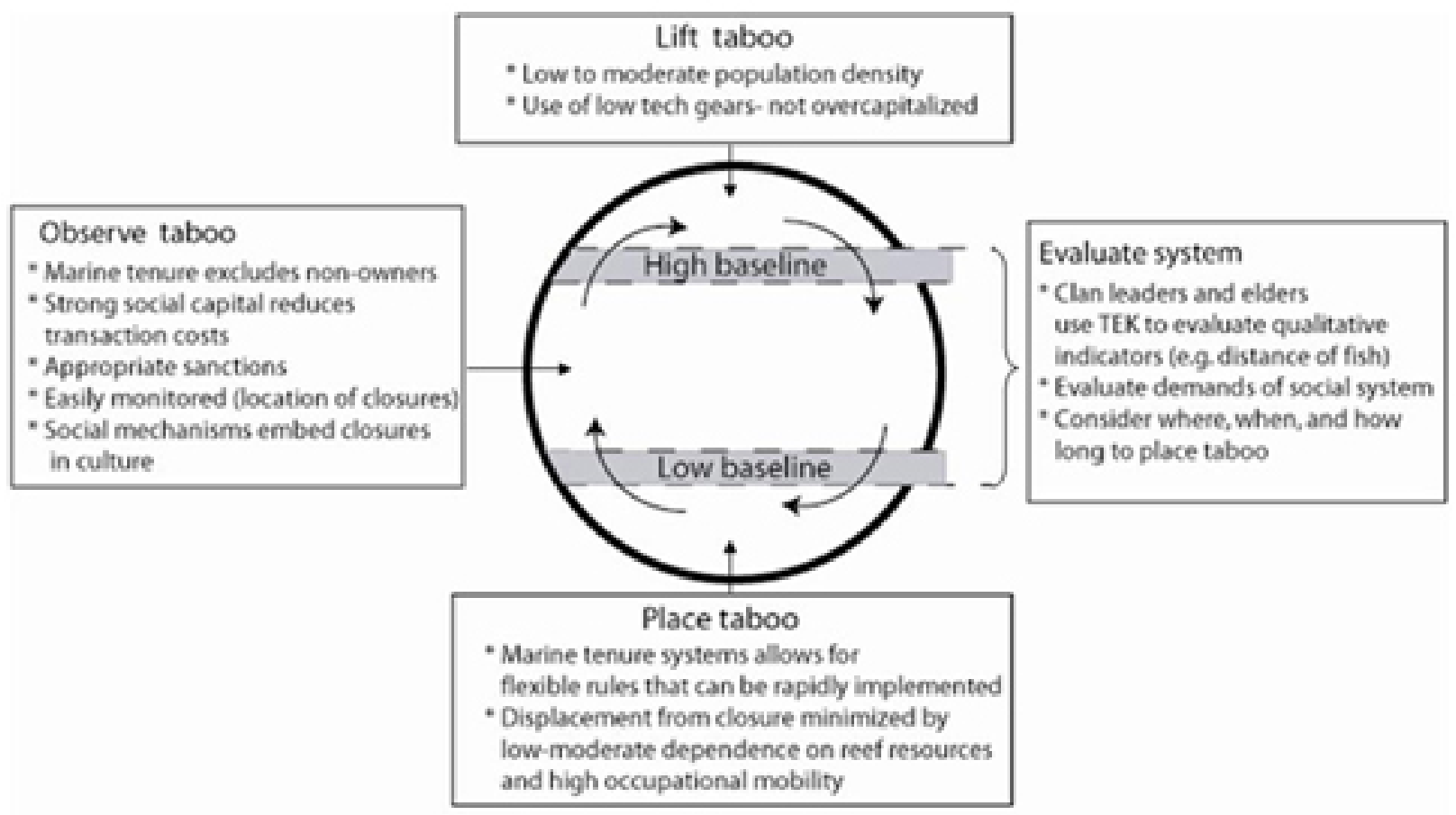

communities also had extremely strong traditional leadership and social mechanisms that embedded the closures into local traditions and customs. For example, traditional ceremonies were regularly held after the taboo was lifted. Cultural internalization of traditional management regimes can help to reinforce awareness of, and justification for, such practices (Berkes et al. 2000, Aswani and Hamilton 2004). This perceived legitimacy of both the practices and the traditional authorities may help to promote compliance with fisheries management regulations resulting in low enforcement and monitoring costs (Sutinen and Kuperan 1999,
Anderies et al. 2004). Periodic closure areas were also placed close to the communities and were therefore easily monitore by community members (Crawford et al. 2004). Sanctions were locally appropriate and graduated and repeat offenses carried a higher penalty (Ostrom 1990, Dietz et al. 2003). Importantly, the communities both perceived and received direct benefits from closures in the form of fish for significant cultural events and increased fish yield during periods when the area is open to fishing.

The third component, opening access to closed 
reefs, has resulted in massive exploitation of reef resources in the highly capitalized, high human population density, and open-access fisheries such as those studied in the Philippines (Russ and Alcala $1998 b$ ). However, we found periodic closures, even when opened to exploitation, had a significantly higher fish biomass than reefs continually open to fishing activity. Relatively low fishing pressure, the use of low-tech boats and gears, and the ability to exclude outsiders from accessing resources in the communities we studied, suggests that recently opened areas may not be subjected to disproportionately intense exploitation. Also, because reefs are not open-access, there is little incentive for individuals to preemptively overexploit resources (Hardin 1968).

The final component of the management cycle, evaluation, occurred continually throughout the adaptive cycle, i.e., after the taboo was placed and resources were rebuilding, and after lifting the taboo as resources declined due to exploitation. Evaluation of the social-ecological system appeared crucial in informing community leaders as to when, where, and how long to place closures. These communities relied on traditional ecological knowledge (TEK) to make sense of, and react to, changes in their social-ecological systems (Johannes 1982, Berkes et al. 2000, Gadgil et al. 2000, Huntington 2000, Drew 2005). Traditional cultural mechanisms such as initiation rights for certain fishing practices, which involve the passing of knowledge, appeared to reinforce and maintain a base of TEK (Berkes et al. 2000).

\section{CONCLUSIONS}

Adaptive strategies are an important component of holistic ecosystem management (Holling 2001), but few examples exist of such management in coral reef fisheries (McManus et al. 1988). This is, in part, because the ability to practice adaptive management may rely on the presence of specific social mechanisms. In particular, institutions must have the capacity to interpret, and respond to, changing resource conditions, and both resource use practices and governance regimes must be flexible enough to allow for rapid decision making (Gunderson 1999).

The adaptive periodic closures we studied were practiced explicitly to meet social goals, including providing food resources at a time of social significance, rather than to fulfill western notions of conservation or resource management. As a result, it is unlikely that these periodic closures can conserve all of the resources and biological processes conserved by large and full protected reserves, i.e., those that are permanently closed to all extractive activities (McClanahan and Graham 2005, McClanahan et al., in press). However, the unfortunate reality in many developing countries is that, despite massive funding efforts by NGOs and development agencies, such fully closed reserves often suffer from low levels of enforcement, monitoring, and compliance (McClanahan 1999, Pollnac et al. 2001) and are thus, in many cases, ineffective at either conserving marine resources or enhancing fisheries. In contrast, we found that adaptive periodic closures increased fish biomass and average fish size, albeit well below the levels that might be expected for unexploited ecosystems (McClanahan and Graham 2005). Furthermore, this strategy achieved high levels of community support and compliance without external financial assistance. We do not suggest that this type of management can replace large fully closed marine reserves and other management strategies, or that the reimplementation of these systems could occur without funding. Instead, we aim to highlight adaptive periodic closures as one of many potential tools in the effort to conserve resources and enhance fisheries.

The applicability of periodic closures is likely limited to situations characterized by a suite of specific social and economic factors, including low human population density, decentralized and flexible control of marine resources, people that adhere to traditions, and low reliance on the resource. However, we suggest that such conditions are present in the coastal communities of many developing nations around the Indo-Pacific, an area of high biodiversity and conservation value. When the proper socioeconomic factors are found, and large, permanently-closed reserves are unrealistic or have repeatedly failed, adaptive periodic closures may be a more viable conservation strategy.

Responses to this article can be read online at: http://www.ecologyandsociety.org/voll1/iss 1/art31/responses/ 


\section{Acknowledgments:}

We thank the leaders and people of Muluk and Kakarotan villages for allowing us to work in their communities and on their reefs, for providing assistance and sharing their valuable knowledge. Thanks to $R$. Arthur for thought-provoking discussions and to R. Ardiwijaya, J. Ben, T. Clark, W. Kiene, I. Laviko, S. Moko, S. Pardede, V. Roring, $J$ Wibowo, and R. Yamuna for assistance with data collection and planning. We also thank the Madang and North Sulawesi Provincial Governments, LIPI, and the PNG National Research Institute. The David and Lucille Packard Foundation supported this research.

\section{LITERATURE CITED}

Allen, G. R., and R. Steene. 1994. Indo-Pacific reef field guide. Tropical reef research, Singapore.

Allen, G. R., and R. Swainston. 1993. Reef fishes of New Guinea. Christensen Research Institute, Madang, Papua New Guinea.

Allen, G. R., and T. B. Werner. 2002. Coral reef fish assessment in the "coral triangle" of Southeast Asia. Environmental Biology of Fishes 65:209-214.

Anderies, J. M.,A. Janssen, and E. Ostrom. 2004. A framework to analyze the robustness of socialecological systems from an institutional perspective. Ecology and Society 9:18.

Aswani, S. 1998. Patterns of marine harvest efforts in southwestern New Georgia, Solomon Islands: resource management or optimal foraging. Ocean and Coastal Management 40:207-235.

Aswani, S. 1999. Common property models of sea tenure: a case study from the Roviana and Vonavona Lagoons, New Georgia, Solomon Islands. Human Ecology 27:417-453.

Aswani, S. 2002. Assessing the effects of changing demographic and consumption patterns on sea tenure regimes in the Roviana Lagoon, Solomon Islands. Ambio 31:272-284.

Aswani, S., and R. Hamilton. 2004. The value of many small versus few large marine protected areas in the Western Solomon Islands. SPC Traditional Marine Resource Management and Knowledge Information Bulletin 16:3-14.

Aswani, S., and P. Weiant. 2004. Scientific Evaluation in women's participatory management: monitoring marine invertebrate refugia in the Solomon Islands. Human Organization 63:301-319.

Berkes, F., J. Colding, and C. Folke. 2000. Rediscovery of traditional ecological knowledge as adaptive management. Ecological Applications 10:1251-1262.

Caddy, J. F. 1999. Fisheries management in the twenty-first century: will new paradigms apply? Reviews in Fish Biology and Fisheries 9:1-43.

Carrier, J. 1987. Marine tenure and conservation in Papua New Guinea. Pages 143-167 in B. McCay and J. Acheson, editors. The question of the commons: the culture and ecology of common resources. The University of Arizona Press, Tuscon, Arizona, USA.

Christie, P. 2004. MPAs as biological successes and social failures in Southeast Asia. Pages 155-164 in J. B. Shipley, editor. Aquatic protected areas as fisheries management tools: design, use, and evaluation of these fully protected areas. American Fisheries Society, Bethesda, Maryland, USA.

Christie, P., B. J. McCay, M. L. Miller, C. Lowe, A. T. White, R. Stoffle, D. L. Fluharty, L. T. McManus, R. Chuenpagdee, C. Pomeroy, D. O. Suman, B. G. Blount, D. Huppert, R. L. V. Eisma, E. Oracion, K. Lowry, and R. B. Pollnac. 2003. Toward developing a complete understanding: a social science research agenda for marine protected areas. Fisheries 28:22-26.

Cinner, J. 2005. Conservation and development in the Indo-Pacific: how social processes affect customary marine tenure. Ecology and Society $\mathbf{1 0}$ (1):36. [online] URL: http://www.ecologyandsociety. org/vol10/iss 1/art36/.

Cinner, J., M. Marnane, and T. McClanahan. 2005a. Conservation and community benefits from traditional coral reef management at Ahus Island, Papua New Guinea. Conservation Biology 19:1714-1723. 
Cinner, J., M. Marnane, T. McClanahan, T. Clark, and J. Ben. 2005b. Trade, tradition, and tenure: influence of sociocultural factors on resource use in Melanesia. Conservation Biology 19:1469-1477.

Cinner, J., and T. McClanahan. In press. Socioeconomic factors that lead to overfishing in small-scale coral reef fisheries of Papua New Guinea. Environmental Conservation.

Colding, J., and C. Folke. 2000. The taboo system: lessons about informal institutions for nature management. Georgetown International Environmental Law Review 12:413-445.

Colding, J., and C. Folke. 2001. Social taboos: "invisible" systems of local resource management and biological conservation. Ecological Applications 11:584-600.

Crawford, B. R., A. Siahainenia, C. Rotinsulu, and A. Sukmara. 2004. Compliance and enforcement of community-based coastal resource management regulations in North Sulawesi, Indonesia. Coastal Management 32:39-50.

Curran, S., and T. S. Agardy. 2002. Common property systems, migration, and coastal ecosystems. Ambio 31:303-305.

Dietz, T., E. Ostrom, and P. C. Stern. 2003. The struggle to govern the commons. Science 302:1907-1912.

Drew, J. 2005. Using traditional ecological knowledge in marine conservation. Conservation Biology 19:1286-1293.

Dulvy, N. K., R. P. Freckleton, and N. V. C. Polunin. 2004. Coral reef cascades and the indirect effects of predator removal by exploitation. Ecology Letters 7:410-416.

Dyer, C. L., and J. R. McGoodwin, editors. 1994. Folk management in the world's fisheries: lessons for modern fisheries management. University of Colorado Press, Niwot, Colorado, USA.

Earn, D. J. D., and P. Rohani. 1999. Complex dynamics in ecology. Trends in Ecology and Evolution 14:43-44.

Foale, S., and B. Manele. 2004. Social and political barriers to the use of marine protected areas for conservation and fishery management in Melanesia. Asia Pacific Viewpoint 45:373-386.

Fogarty, M. J. 1999. Essential habitat, marine reserves, and fishery management. Trends in Ecology and Evolution 14:133-134.

Folke, C., T. Hahn, P. Olsson, and J. Norberg. 2005. Adaptive governance of social-ecological systems. Annual Review of Environment and Resources 30:441-473.

Froese, R., and D. Pauly, editors. 2000. FishBase 2000: concepts, design, and data sources. The International Center for Living Aquatic Resources Management (ICLARM), Los Baños, Laguna, Philippines.

Gadgil, M., P. R. Seshagiri Rao, G. Utkarsh, P. Pramod, and A. Chhatre. 2000. New meanings for old knowledge: the people's biodiversity registers program. Ecological Applications 10:1307-1317.

Green, A., and P. Craig. 1999. Population size and structure of giant clams at Rose Atoll, an important refuge in the Samoan Archipelago. Coral Reefs 18:205-211.

Greene, L. E., and W. S. Alevizon. 1989. Comparative accuracies of visual assessment methods for coral reef fishes. Bulletin of Marine Science 44:899-912.

Guénette, S., T. Lauck, and C. Clark. 1998. Marine reserves: from Beverton and Holt to the present. Reviews in Fish Biology and Fisheries 8:251-272.

Gunderson, L. 1999. Resilience, flexibility, and adaptive management-antidotes for spurious certitude? Conservation Ecology 3(1):7.

Hall, S. J. 1998. Closed areas for fisheries management - the case consolidates. Trends in Ecology and Evolution 13:297-298.

Hardin, G. 1968. The tragedy of the commons. Science 162: 1243-1248.

Henry, G. T. 1990. Practical sampling. Sage, Newbury Park, California, USA.

Holling, C. S. 2001. Understanding the complexity 
of economic, ecological, and social systems. Ecosystems 4:390-405.

Hooper, D. U., F. S. Chapin, J. J. Ewel, A. Hector, P. Inchausti, S. Lavorel, J. H. Lawton, D. M. Lodge, M. Loreau, S. Naeem, B. Schmid, H. Setälä, A. J. Symstad, J. Vandermeer, and D. A. Wardle. 2005. Effects of biodiversity on ecosystem functioning: a consensus of current knowledge. Ecological Monographs 75:3-35.

Hughes, T. P., A. H. Baird, D. R. Bellwood, M. Card, S. R. Connolly, C. Folke, R. Grosberg, 0. Hoegh-Guldberg, J. B. C. Jackson, J. Kleypas, J. M. Lough, P. Marshall, M. Nyström, S. R. Palumbi, J. M. Pandolfi, B. Rosen, and J. Roughgarden. 2003. Climate change, human impacts, and the resilience of coral reefs. Science 301:929-933.

Huntington, H. P. 2000. Using traditional ecological knowledge in science: methods and applications. Ecological Applications 10:1270-1274.

Hviding, E. 1983. Keeping the sea: aspects of marine tenure in Marovo Lagoon, Solomon Islands. Pages 9-44 in K. Ruddle and R. E. Johannes, editors. Traditional marine resource management in the Pacific Basin: an anthology. United Nations Environmental and Cultural Organization, Jakarta, Indonesia.

Hviding, E. 1996. Guardians of the Marovo Lagoon: practice, place, and politics in maritime Melanesia. University Press of Hawaii, Honolulu, Hawaii, USA.

Hviding, E. 1998. Contextual flexibility: present status and future of customary marine tenure in Solomon Islands. Ocean and Coastal Management 40:253-269.

Johannes, R. E. 1978. Traditional marine conservation methods in Oceania and their demise. Annual Review of Ecology and Systematics 9:349-364.

Johannes, R. E. 1981. Words of the lagoon: fishing and marine lore in the Palau district of Micronesia. University of California Press, Berkeley, California, USA.

Johannes, R. E. 1982. Traditional conservation methods and protected marine areas in Oceania.
Ambio 11:258-261.

Johannes, R. E. 2002a. Recent evolution of villagebased marine resource management in Vanuatu. Secretariat of the Pacific Community (SPC), Traditional Marine Resource Management and Knowledge Information Bulletin 14:8-21.

Johannes, R. E. 2002b. The renaissance of community-based marine resource management in Oceania. Annual Review of Ecological Systems 33:317-340.

Koczberski, G., and G. N. Curry. 2004. Divided communities and contested landscapes: mobility, development, and shifting identities in migrant destination sites in Papua New Guinea. Asia Pacific Viewpoint 45:357-371.

Kramer, R., S. M. H. Simanjuntak, and C. Liese. 2002. Migration and fishing in Indonesian coastal villages. Ambio 31:367-372.

Lloyd, A. L., and R. M. May. 1999. Synchronicity, chaos, and population cycles: spatial coherence in an uncertain world. Trends in Ecology and Evolution 14:417-418.

Magurran, A. E. 2004. Measuring biological diversity. Blackwell, Oxford, UK.

Malinowski, B. 1922. Argonauts of the Western Pacific. Routledge and Kegan Paul, London, UK.

Malinowski, B. 1935. Coral gardens and their magic. George Allen and Unwin, London, UK.

Mantjoro, E. 1996. Management of traditional common fishing grounds-the experience of the Para community, Indonesia. Coastal Management 3:229-250.

McClanahan, T., and S. H. Shafir. 1990. Causes and consequences of sea urchin abundance and diversity in Kenyan coral reef lagoons. Oecologia 83:362-370.

McClanahan, T. R. 1999. Is there a future for coral reef parks in poor tropical countries. Coral Reefs 18:321-325.

McClanahan, T. R. 2000. Recovery of a coral reef keystone predator, Balistapus undulatus, in East African marine parks. Biological Conservation 
94:191-198.

McClanahan, T. R., and S. Mangi. 2000. Spillover of exploitable fishes from a marine park and its effect on the adjacent fishery. Ecological Applications 10:1792-1805.

McClanahan, T. R., and S. Mangi. 2004. Gearbased management of a tropical artisanal fishery based on species selectivity and capture size. Fisheries Management and Ecology 11:51-60.

McClanahan T. R., and N. A. J. Graham. 2005. Recovery trajectories of coral reef fish assemblages within Kenyan marine protected areas. Marine Ecology Progress Series 294:241-248.

McClanahan, T. R., E. Verheij, and J. Maina. 2006. Comparing management effectiveness of a marine park and a multiple-use collaborative management area in East Africa. Aquatic conservation: marine and freshwater ecosystems. 16:147-165

McManus, J. W., E. M. Ferrer, and W. L. Campos. 1988. A village-level approach to coastal adaptive management and resource assessment (CAMRA). Pages 381-386 in Proceedings of the 6th International Coral Reef Symposium, Townsville, Australia.

Myers, R. F. 1999. Micronesian reef fishes. Third Edition, Coral Graphics Barrigada, Guam.

Olsson, P., C. Folke, and F. Berkes. 2004. Adaptive comanagement for building resilience in socialecological systems. Environmental Management 34:75-90.

Ostrom, E. 1990. Governing the commons: the evolution of institutions for collective action. Cambridge University Press, Cambridge, UK.

Paulay, G. 1997. Diversity and distribution of reef organisms. Pages 298-353 in C. Birkeland, editor. Life and death of coral reefs. Chapman and Hall, New York, New York, USA.

Pet-Soede, L. 2000. Options for co-management of an Indonesian coastal fishery. Dissertation. Wageningen University, Wageningen, The Netherlands.

Pollnac, R. B., and B. Crawford. 2000. Assessing behavioral aspects of coastal resource use. Coastal
Resources Center, University of Rhode Island, Narragansett, Rhode Island, USA.

Pollnac, R. B., B. R. Crawford, and M. L. G. Gorospe. 2001. Discovering factors that influence the success of community-based marine protected areas in the Visayas, Philippines. Ocean and Coastal Management 44:683-710.

Pollnac, R. B., and J. C. Johnson. 2005. Folk management and conservation of marine resources: towards a theoretical and methodological assessment. Pages 33-50 in N. Kishigami and J. M. Savelle, editors. Indigenous use and management of marine resources, Senri Ethnological Studies 67. National Museum of Ethnology, Osaka, Japan.

Polunin, N. V. C. 1984. Do traditional marine "reserves" conserve? A view of Indonesian and New Guinean evidence. Pages 267-284 in K. Ruddle and T. Akimichi, editors. Maritime institutions in the Western Pacific. National Museum of Ethnology, Osaka, Japan.

Polunin, N. V. C., and C. M. Roberts. 1996. Reef fisheries. Chapman and Hall, London, UK.

Pretty, J. 2003. Social capital and the collective management of resources. Science 302:1912-1914.

Randall, J. E., G. R. Allen, and R. Steene, editors. 1997. Fishes of the Great Barrier Reef and Coral Sea, Second Edition. University of Hawaii Press, Honolulu, Hawaii.

Reaka-Kudla, M. 1997. The global biodiversity of coral reefs: a comparison with rainforests. Pages 83-108 in E. O. Wilson, editor. Biodiversity II: understanding and protecting natural resources. Joseph Henry/National Academy Press, Washington, D.C., USA.

Russ, G. R. 2002. Yet another review of marine reserves as reef fishery management tools. Pages 421-443 in P. F. Sale, editor. Coral reef fishes: dynamics and diversity in a complex ecosystem. Academic Press, San Diego, California, USA.

Russ, G. R., and A. C. Alcala. 1998a. Natural fishing experiments in marine reserves 1983-1993: community and trophic responses. Coral Reefs 17:383-397.

Russ, G. R., and A. C. Alcala. 1998b. Natural 
fishing experiments in marine reserves 1983-1993: roles of life history and fishing intensity in family responses. Coral Reefs 17:399-416.

Russ, G. R., and A. C. Alcala. 2003. Marine reserves: rates and patterns of recovery and decline of predatory fish. Ecological Applications 13:1553-1565.

Russ G. R., and A. C. Alcala. 2004. Marine reserves: long-term protection is required for full recover of predatory fish populations. Oecologia 138:622-627.

Ruttan, L. M. 1998. Closing the commons: cooperation for gain or restraint? Human Ecology 26:43-66.

Ruttan, L. M., and M. Borgerhoff Mulder. 1999. Are East African pastoralists truly conservationists? Current Anthropology 40:621-652.

Scheaffer, R. L., W. I. Mendenhall, and L. Ott. 1996. Elementary survey sampling. Wadsworth, Belmont, California, USA.

Scheffer, M., F. Westley, W. Brock, and M. Holmgren. 2002. Dynamic interaction of societies and ecosystems:linking theories from ecology, economy, and society. Pages 195-239 in L. Gunderson and C. S. Holling, editors. Panarchy: understanding transformations in human and natural systems. Island Press, Washington D.C., USA.

Siegel, S., and N. J. Castellan. 1988. Nonparametric statistics for the behavioral sciences, Second Edition. McGraw-Hill, New York, New York, USA.

Sutinen, J. G., and K. Kuperan. 1999. A socioeconomic theory of regulatory compliance. International Journal of Socio Economics 26:174-193.

Veron, J.E. N. 2000. Corals of the world. Australian Institute of Marine Science, Townsville, Australia.

Villanoy, C. L., A. R. Juinio, and L. A. Menez. 1988. Fishing mortality rates of giant clams (Family Tridacnidae) from the Sulu Archipelago and Southern Palawan, Philippines. Coral Reefs 7:1-5.

Wilkinson, C., editor. 2002. Status of coral reefs of the world: 2002. Australian Institute of Marine Science, Townsville, Australia.

Wright,A. 1985. Marine resource use in Papua New Guinea: can traditional concepts and contemporary development be integrated? Pages 53-77 in K. Ruddle and R. E. Johannes, editors. The traditional knowledge and management of coastal systems in Asia and the Pacific. United Nations Environmental and Cultural Organization, Jakarta, Pusat, Indonesia. 
APPENDIX 1. List of species comprising each family in Muluk and their associated life history and resilience to overfishing

FAMILY

Acanthuridae

Acanthuridae

Acanthuridae

Acanthuridae

Acanthuridae

Acanthuridae

Acanthuridae

Acanthuridae

Acanthuridae

Acanthuridae

Balistidae

Chaetodontidae

Chaetodontidae

Chaetodontidae

Chaetodontidae

Chaetodontidae

\section{SPECIES}

Acanthurus lineatus

Acanthurus nigricans

Acanthurus nigrofuscus

Acanthurus pyroferus

Ctenochaetus binotatus

Ctenochaetus striatus

Ctenochaetus strigosus

Naso lituratus

Naso vlamingi

Zebrasoma scopas

Balistapus undulatus

Chaetodon baronessa

Chaetodon citrinellus

Chaetodon kleinii

Chaetodon ornatissimus

Chaetodon oxycephala
Population doubling time

1.4-4.4 years

4.5-14 years

1.4-4.4 years

1.4-4.4 years

1.4-4.4 years

$<15$ months

$<15$ months

1.4-4.4 years

4.5-14 years

4.5-14 years

1.4-4.4 years

$<15$ months

$<15$ months

$<15$ months

$<15$ months

$<15$ months
Resilience to overfishing

Medium

Low

Medium

Medium

Medium

High

High

Medium

Low

Medium

Medium

High

High

High

High

High 


\begin{tabular}{|c|c|c|c|}
\hline Chaetodontidae & Chaetodon pelewensis & $<15$ months & High \\
\hline Chaetodontidae & Chaetodon semion & $<15$ months & High \\
\hline Chaetodontidae & Chaetodon trifascialis & 1.4-4.4 years & Medium \\
\hline Chaetodontidae & Chaetodon trifasciatus & $<15$ months & High \\
\hline Chaetodontidae & Chaetodon vagabundas & $<15$ months & High \\
\hline Chaetodontidae & Forcipiger longirostris & $<15$ months & High \\
\hline Chaetodontidae & Hemitaurichthys polylepis & $<15$ months & High \\
\hline Chaetodontidae & Heniochus chrysostomus & $<15$ months & High \\
\hline Chaetodontidae & Heniochus varius & $<15$ months & High \\
\hline Haemulidae & Plectorhinchus chaetodonoides & 4.5-14 years & Low \\
\hline Haemulidae & Plectorhinchus orientalis & $4.5-14$ years & Low \\
\hline Labridae & Anampses neoguinicus & 1.4-4.4 years & Medium \\
\hline Labridae & Bodianus diana & 1.4-4.4 years & Medium \\
\hline Labridae & Bodianus mesothorax & 1.4-4.4 years & Medium \\
\hline Labridae & Cheilinus chlorurus & 4.5-14 years & Low \\
\hline Labridae & Cheilinus diagramma & NA & NA \\
\hline Labridae & Cheilinus fasciatus & NA & NA \\
\hline Labridae & Cheilinus oxycephalis & 1.4-4.4 years & Medium \\
\hline Labridae & Chelio inermis & 4.5-14 years & Low \\
\hline Labridae & Cheorodon anchorago & NA & NA \\
\hline
\end{tabular}




\begin{tabular}{|c|c|c|c|}
\hline Labridae & Epibulus insidiator & $4.5-14$ years & Low \\
\hline Labridae & Gomphosus varius & $4.5-14$ years & Low \\
\hline Labridae & Halichoeres hortulanus & $1.4-4.4$ years & Medium \\
\hline Labridae & Halichoeres leucurus & $1.4-4.4$ years & Medium \\
\hline Labridae & Halichoeres marginatus & $1.4-4.4$ years & Medium \\
\hline Labridae & Halichoeres melanurus & $1.4-4.4$ years & Medium \\
\hline Labridae & Hemigymnus melapterus & $4.5-14$ years & Low \\
\hline Labridae & Hemigymnus fasciatus & 4.5-14 years & Low \\
\hline Labridae & Labrichthyes unilineatus & $1.4-4.4$ years & Medium \\
\hline Labridae & Labroides dimidiatus & $1.4-4.4$ years & Medium \\
\hline Labridae & Macropharyngodon meleagris & $1.4-4.4$ years & Medium \\
\hline Labridae & Pseudochelinus hexataenia & $<15$ months & High \\
\hline Labridae & Stethojulis bandanensis & $1.4-4.4$ years & Medium \\
\hline Labridae & Thalasoma amblycephalum & $1.4-4.4$ years & Medium \\
\hline Labridae & Thalasoma hardwicki & $<15$ months & High \\
\hline Lethrinidae & Gnathodentex aurolineatus & $1.4-4.4$ years & Medium \\
\hline Lethrinidae & Lethrinus erythricanthus & $4.5-14$ years & Low \\
\hline Lethrinidae & Monotaxis grandulosus & $4.5-14$ years & Low \\
\hline Lutjanidae & Aphareus rutilans & $4.5-14$ years & Low \\
\hline Lutjanidae & Macolor macularis & $4.5-14$ years & Low \\
\hline
\end{tabular}




\begin{tabular}{|c|c|c|c|}
\hline Lutjanidae & Macolor niger & $4.5-14$ years & Low \\
\hline Mullidae & Parupenus multifasciatus & $1.4-4.4$ years & Medium \\
\hline Mullidae & Parupenus cyclostomus & $1.4-4.4$ years & Medium \\
\hline Nemipteridae & Scolopsis bilineata & $1.4-4.4$ years & Medium \\
\hline Pomacanthidae & Centropyge vroliki & $1.4-4.4$ years & Medium \\
\hline Pomacanthidae & Pygoplites diacanthus & $1.4-4.4$ years & Medium \\
\hline Scaridae & Bolbometapon muricatum & $4.5-14$ years & Low \\
\hline Scaridae & Calatomus carolinus & NA & NA \\
\hline Scaridae & Cetoscarus bicolor & $1.4-4.4$ years & Medium \\
\hline Scaridae & Chlororus microrhinos & NA & NA \\
\hline Scaridae & Chlorurus bleekeri & $1.4-4.4$ years & Medium \\
\hline Scaridae & Chlorurus pyrhurus & 1.4-4.4 years & Medium \\
\hline Scaridae & Chlorurus sordidus & $1.4-4.4$ years & Medium \\
\hline Scaridae & Scarus chameleon & $1.4-4.4$ years & Medium \\
\hline Scaridae & Scarus dimidiatus & $1.4-4.4$ years & Medium \\
\hline Scaridae & Scarus flavipectoralis & $1.4-4.4$ years & Medium \\
\hline Scaridae & Scarus niger & $1.4-4.4$ years & Medium \\
\hline Scaridae & Scarus spinus & $1.4-4.4$ years & Medium \\
\hline Serranidae & Cephalopholis urodeta & $1.4-4.4$ years & Medium \\
\hline Serranidae & Epinephalus fuscoguttatus & $1.4-4.4$ years & Medium \\
\hline
\end{tabular}




\begin{tabular}{llcc}
\hline Serranidae & Epinephalus spilotoceps & $1.4-4.4$ years & Medium \\
Siganidae & Siganus coralinus & $<15$ months & High \\
Siganidae & Siganus doliatus & $<15$ months & High \\
Siganidae & Siganus puellus & $1.4-4.4$ years & Medium
\end{tabular}

Biomass and average size of families in bold were significantly higher inside periodic closures 
APPENDIX 2. List of species comprising each family in Muluk and their associated life history and resilience to overfishing

\section{FAMILY}

Acanthuridae

Acanthuridae

Acanthuridae

Acanthuridae

Acanthuridae

Acanthuridae

Acanthuridae

Acanthuridae

Balistidae

Balistidae

Balistidae

Chaetodontidae

Chaetodontidae

Chaetodontidae

Chaetodontidae

Chaetodontidae
SPECIES

Acanthurus nigricans

Acanthurus nigrofuscus

Acanthurus pyroferus

Acanthurus thompsoni

Ctenochaetus striatus

Naso lituratus

Naso vlamingi

Zebrasoma scopas

Balistapus undulatus

Melichthyes vidua

Sufflamen fraenatus

Chaetodon auriga

Chaetodon citrinellus

Chaetodon ephippium

Chaetodon kleinii

Chaetodon rafflesi
Population doubling time

Resilience

4.5-14 years

Low

1.4-4.4 years

Medium

1.4-4.4 years

Medium

1.4-4.4 years

Medium

$<15$ months

High

1.4-4.4 years

Medium

4.5-14 years

Low

4.5-14 years

Medium

1.4-4.4 years

Medium

1.4-4.4 years

Medium

1.4-4.4 years

Medium

$<15$ months

High

$<15$ months

High

1.4-4.4 years

Medium

$<15$ months

High

$<15$ months

High 


\begin{tabular}{|c|c|c|c|}
\hline Chaetodontidae & Chaetodon reticulatus & $<15$ months & High \\
\hline Chaetodontidae & Chaetodon trifasciatus & 1.4-4.4 years & Medium \\
\hline Chaetodontidae & Chaetodon ulietensis & $<15$ months & High \\
\hline Chaetodontidae & Chaetodon unimaculatus & $<15$ months & High \\
\hline Chaetodontidae & Chaetodon vagabundas & $<15$ months & High \\
\hline Chaetodontidae & Forcipiger longirostris & $<15$ months & High \\
\hline Chaetodontidae & Hemitaurichthys polylepis & $<15$ months & High \\
\hline Chaetodontidae & Heniochus chrysostomus & $<15$ months & High \\
\hline Chaetodontidae & Heniochus varius & $<15$ months & High \\
\hline Haemulidae & Plectorhinchus chaetodonoides & 4.5-14 years & Low \\
\hline Haemulidae & Plectorhinchus lineatus & 4.5-14 years & Low \\
\hline Labridae & Anampses caerulopunctatus & 4.5-14 years & Low \\
\hline Labridae & Anampses meleagrides & 4.5-14 years & Low \\
\hline Labridae & Anampses twistii & 4.5-14 years & Low \\
\hline Labridae & Cheilinus celebicus & NA & NA \\
\hline Labridae & Cheilinus chlorurus & 4.5-14 years & Low \\
\hline Labridae & Cheilinus diagramma & NA & NA \\
\hline Labridae & Cheilinus oxycephalis & 1.4-4.4 years & Medium \\
\hline Labridae & Cheilinus unifasciatus & NA & NA \\
\hline Labridae & Cirrhilabrus cyanopleura & $1.4-4.4$ years & Medium \\
\hline
\end{tabular}




\begin{tabular}{|c|c|c|c|}
\hline Labridae & Cirrhilabrus punctatus & $1.4-4.4$ years & Medium \\
\hline Labridae & Coris gaimardi & $4.5-14$ years & Low \\
\hline Labridae & Coris shroederi & NA & NA \\
\hline Labridae & Epibulus insidiator & $4.5-14$ years & Low \\
\hline Labridae & Gomphosus varius & $4.5-14$ years & Low \\
\hline Labridae & Halichoeres podostigma & 1.4-4.4 years & Medium \\
\hline Labridae & Halichoeres biocellatus & $1.4-4.4$ years & Medium \\
\hline Labridae & Halichoeres hortulanus & $1.4-4.4$ years & Medium \\
\hline Labridae & Halichoeres leucurus & 1.4-4.4 years & Medium \\
\hline Labridae & Halichoeres marginatus & $1.4-4.4$ years & Medium \\
\hline Labridae & Halichoeres melanurus & 1.4-4.4 years & Medium \\
\hline Labridae & Halichoeres scapularis & 1.4-4.4 years & Medium \\
\hline Labridae & Hemigymnus melapterus & $4.5-14$ years & Low \\
\hline Labridae & Hemigymus fasciatus & $4.5-14$ years & Low \\
\hline Labridae & Hologymnosus annulatus & 4.5-14 years & Low \\
\hline Labridae & Labrichthyes unilineatus & 1.4-4.4 years & Medium \\
\hline Labridae & Labroides bicolor & 1.4-4.4 years & Medium \\
\hline Labridae & Labroides dimidiatus & 1.4-4.4 years & Medium \\
\hline Labridae & Labroides pectoralis & 1.4-4.4 years & Medium \\
\hline Labridae & Macropharyngodon meleagris & $1.4-4.4$ years & Medium \\
\hline
\end{tabular}




\begin{tabular}{|c|c|c|c|}
\hline Labridae & Oxycheilinus bimaculatus & $1.4-4.4$ years & Medium \\
\hline Labridae & Pseudochelinus hexataenia & $<15$ months & High \\
\hline Labridae & Pseudochelinus octotaenia & $1.4-4.4$ years & Medium \\
\hline Labridae & Stethojulis bandanensis & $1.4-4.4$ years & Medium \\
\hline Labridae & Thallasoma amblycephalum & $1.4-4.4$ years & Medium \\
\hline Labridae & Thallasoma hardwicki & $<15$ months & High \\
\hline Labridae & Thallasoma lunare & $1.4-4.4$ years & Medium \\
\hline Labridae & Thallasoma quinquivitatum & $1.4-4.4$ years & Medium \\
\hline Lethrinidae & Lethrinus erythricanthus & $4.5-14$ years & Low \\
\hline Lethrinidae & Monotaxis grandoculis & $4.5-14$ years & Low \\
\hline Lutjanidae & Labroides pectoralis & 1.4-4.4 years & Medium \\
\hline Mullidae & Parapaeneus bifasciatus & 1.4-4.4 years & Medium \\
\hline Mullidae & Parupenus multifasciatus & 1.4-4.4 years & Medium \\
\hline Nemipteridae & Scolopsis bilineata & 1.4-4.4 years & Medium \\
\hline Nemipteridae & Scolopsis lineatus & $<15$ months & High \\
\hline Nemipteridae & Scolopsis margaritifera & $<15$ months & High \\
\hline Pomacanthidae & Centropyge bispinosus & $<15$ months & High \\
\hline Pomacanthidae & Centropyge vroliki & 1.4-4.4 years & Medium \\
\hline Pomacanthidae & Pygoplites diacanthus & 1.4-4.4 years & Medium \\
\hline Scaridae & Calatomus carolinus & NA & NA \\
\hline
\end{tabular}




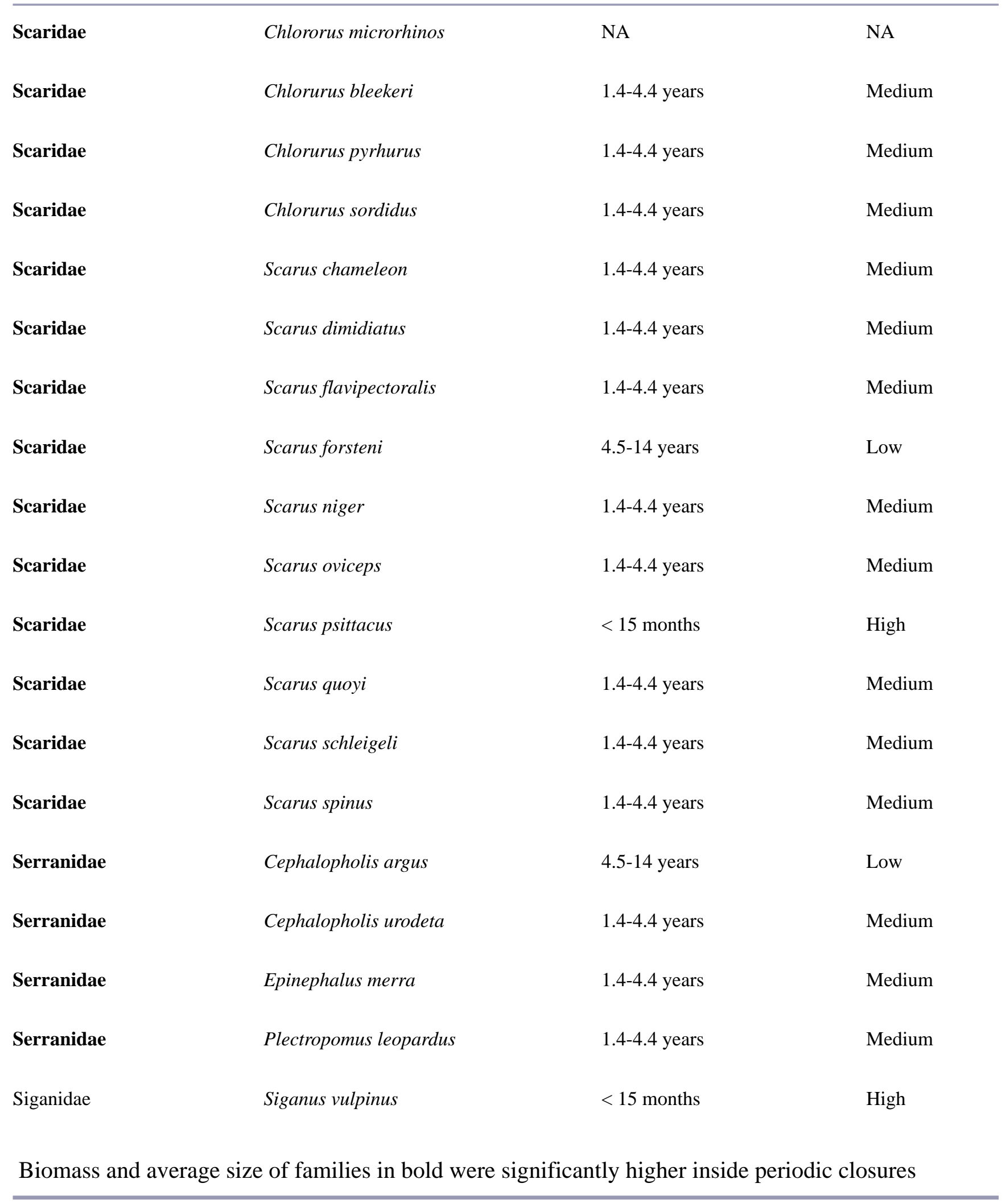

